\title{
Ethnomedicinal Uses, Phytochemistry and Pharmacology of Dorema Species (Apiaceae): A Review
}

\author{
Elaheh Zibaee ${ }^{1}$, Mohammad Sadegh Amiri ${ }^{2}$, Zahra Boghrati ${ }^{1}$, Faeghe Farhadi ${ }^{3}$, Mahin Ramezani ${ }^{4,5}$, \\ Seyed Ahmad Emami ${ }^{1 *}$, Amirhossein Sahebkar ${ }^{6,7,8,9}$
}

${ }^{1}$ Department of Traditional Pharmacy, School of Pharmacy, Mashhad University of Medical Sciences, Mashhad, Iran

${ }^{2}$ Department of Biology, Payame Noor University, Tehran, Iran

${ }^{3}$ Department of Pharmacognosy, School of Pharmacy, Mashhad University of Medical Sciences, Mashhad, Iran

${ }^{4}$ Nanotechnology Research Center, Mashhad University of Medical Sciences, Mashhad, Iran

${ }^{5}$ Pharmaceutical Research Center, Mashhad University of Medical Sciences, Mashhad, Iran

${ }^{6}$ Halal Research Center of IRI, FDA, Tehran, Iran

${ }^{7}$ Biotechnology Research Center, Pharmaceutical Technology Institute, Mashhad University of Medical Sciences, Mashhad, Iran

${ }^{8}$ Neurogenic Inflammation Research Center, Mashhad University of Medical Sciences, Mashhad, Iran

${ }^{9}$ Polish Mother's Memorial Hospital Research Institute (PMMHRI), Lodz, Poland

Received March 25, 2018

Reviewed July 31, 2020

Accepted August 28, 2020

*Correspondence

Seyed Ahmad Emami

Department of Traditional Pharmacy,

School of Pharmacy, Mashhad University

of Medical Sciences, Mashhad, Iran

Tel: +0985131801267

E-mail: emamia@mums.ac.ir
The application of antique medical instructions, practices, skills and knowledge has been considered as the most affordable treatment in many developing countries. The use of these preparations and prescriptions over generations has made a useful and valuable guide for drug discovery in modern medicine. Medical herbs have been of a high importance for this purpose. The genus Dorema, of Apiaceae family (Umbelliferae) has a wide use in ethnobotany and traditional medicine around the world. It has been used as a treatment for CNS disease, convulsion, upper respiratory tract problems, gastrointestinal disorder and high blood sugar. Furthermore, phytochemical investigations have reported Dorema species to contain a wide range of constituents including terpenes, coumarins and phenolic compounds. The current review summarizes comprehensive information regarding botany, phytochemistry andpharmacological aspects of Dorema spp.

Keywords: Dorema, phytochemistry, pharmacology

\section{INTRODUCTION}

The genus Dorema D. Don, belongs to the Apiaceae family (Umbelliferae) with important medicinal and aromatic species. It contains a total of 12 accepted species worldwide (http:// www.theplantlist.org). Among them 7 are represented in Iran [1]. The genus has been used as a food additive as well as for various medicinal purposes in traditional and folklore medicine around the world [2].

Dorema ammoniacum, commonly known as "Ushaq" or "Vasha", is considered as one of the most studied species [3]. Being rich in ammoniacum, a medicinal gum-resin, it has been mentioned in Islamic Traditional Medicine (ITM) as a treatment for various disorders, such as gastrointestinal, upper respi- ratory tract and central nervous systems problems [3-5]. Furthermore, numerous chemical compounds including terpenes, coumarins and phenolic compounds have been isolated from Dorema species and a wide range of pharmacological activities including anti-microbial, anti-inflammatory, antioxidant, cytotoxicity, anticonvulsant, anti-diabetic and hypolipidemic activities have been reported from this genus in modern medicine [6].

In the current review we present a comprehensive report on ethnobotanical and traditional uses, phytochemical compounds and pharmacological activities of the genus Dorema. 


\section{BOTANY}

\section{Botanical description of Dorema spp.}

Dorema species are large monocarpic perennial plant, with thickened storage roots, and have large simple umbels with regular flowers, bisexual and staminate, the bisexual on upper branches and the staminate on lower, rarely flowers mixed; Involucre of few caducous leaflets, or lacking; calyx 5-toothed, indistinct; petals are yellow, cream- colored or greenish yellow, nerve darker, ovate- elongate, with inward curved tip; The stigmas are truncate or thickened; stylopodium is flat, fleshy with lobed broadened margin, becoming cup-shaped; ovary is cylindrical, faintly ribbed. Fruit with free carpophore, dorsally piano- compressed, elliptic, with filiform protruding ribs, 2 lateral ribs fusing with unthicken, whitish margin. Geographically, Dorema is distributed in the Caucasus and the southern parts of Central Asia. It also grows in Iran, Afghanistan and Baluchistan. Its northernmost representative (Dorema microcarpum Korovin.) appears in Central Asia, its southern limit lies in Tien Shan. Dorema is typical in arid conditions and most species occur in dry foothills and hills, some grow in deserts.

They are confined to calcareous soils, often mixed with rock debris. One species, Dorema sabulosum Litv. is a typical psammophyte $[7,8]$. According to The Plant List, there are 25 scientific plant names of species rank for the genus Dorema, of these 12 are accepted species names (http://www.theplantlist.org). In Iran, the genus Dorema is represented by seven species, namely, D. aitchisonii Korovin ex Pimenov, D. ammoniacum D.Don, D. aucheri Boiss., D. aureum Stocks, D. glabrum Fisch. \& C.A. Mey., D. hyrcanum Koso-Pol. and D. kopetdaghense Pimenov which among them $D$. aucheri Boiss. is endemic to Iran. Dorema kopetdaghensePimenovin Flora Iranica, treated as a synonym of $D$. hyrcanum Koso-Pol. However, phylogenetic analysis of nrDNA internal transcribed spacer (ITS) sequences showed that these two species should be retained as separate species $[1,9$, 10]. Table 1 summarizes all synonyms of Dorema species based on the website "TPL" (http://www.theplantlist.org).

\section{Threats and conservation priorities}

The genus Dorema, contains monocarpic perennial species, so that only once produces flowers during the life cycle and only reproduces through seeds. These plants are potentially endangered and vulnerable taxa [11]. Some of these taxa such
Table 1. Scientific names and synonyms of reported Dorema species worldwide [according to The Plant List (2013)]

\begin{tabular}{|c|c|c|}
\hline No & Dorema species (Accepted names) & Synonyms \\
\hline 1 & D. aitchisonii Korovin ex Pimenov & \\
\hline 2 & D. ammoniacum D.Don & $\begin{array}{l}\text { D. gummiferum (Jaub. \& } \\
\text { Spach) K.M.Korol. } \\
\text { D. hirsutum Lofius ex } \\
\text { I.G.Borshch. }\end{array}$ \\
\hline 3 & D. aucheri Boiss. & $\begin{array}{l}\text { D. robustum Lofius ex } \\
\text { I.G.Borshch. }\end{array}$ \\
\hline 4 & D. aureum Stocks & \\
\hline 5 & D. badhysi Pimenov & \\
\hline 6 & D. balchanorum Pimenov & \\
\hline 7 & D. glabrum Fisch. \& C.A.Mey. & \\
\hline 8 & D. hyrcanumKoso-Pol. & D. gummiferum auct. \\
\hline 9 & D. karatavienseKorovin & \\
\hline 10 & D. kopetdaghense Pimenov & \\
\hline 11 & D. microcarpum Korovin & $\begin{array}{l}\text { D. namanganicum K.M. } \\
\text { Korol. }\end{array}$ \\
\hline 12 & D. sabulosum Litv. & $\begin{array}{c}\text { D. sabulosum var. } \\
\text { borszczowii Litv. }\end{array}$ \\
\hline
\end{tabular}

as $D$. aucheri are narrow-range endemics which occur only in a few specialized niches. $D$. aucheri is considered as a unique endemic species which is intensively collected. Overexploitation of this plant has caused a significant decrease in its population in the area [12]. Furthermore, some others are sub-endemics with threatened species including $D$. ammoniacum, and $D$. kopetdaghense. Today, D. kopetdaghense is also considered as endangered in the IUCN Red List of threatened Species [13]. It has been used in traditional medicine from ancient times [2].

Dorema ammoniacum commonly known as "Ushaq" or "Vasha" is one of the most important industrial and medicinal plants of Iran which has been used in ethnobotanical since ancient times. It is endangered due to superfluous and unsustainable harvesting methods [3,4]. Dorema glabrum is another endangered species that grows in loamy or rocky slopes of $\mathrm{Na}$ khichevan, Autonomous Republic- Azerbaijan, Armenia and Iran $[1,10]$. The plant has immense applications as an herbal remedy or food additive in these regions. Over harvesting from wild populations and destructive collecting methods, are considered as serious threats that often lead to disappearance of these taxa, and must be avoided. There is an urgent need for conservation priorities and management strategies for all taxa assigned to a threat category through seed and gene banking, and planting in botanical gardens. Otherwise, we will lose these 
Table 2. Chemical composition from different parts of Dorema species

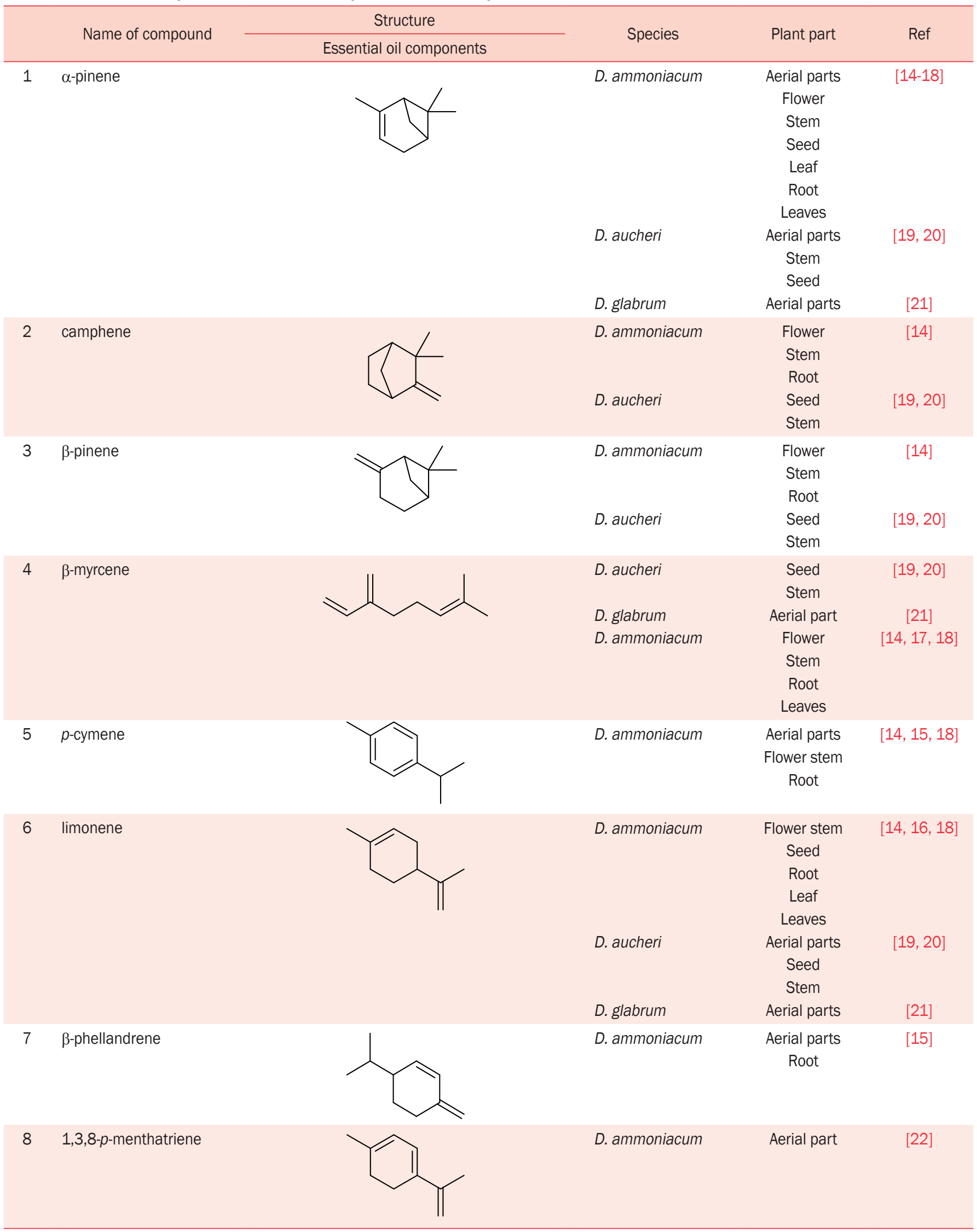


Elaheh Zibaee, et al.

Table 2. Continued 1

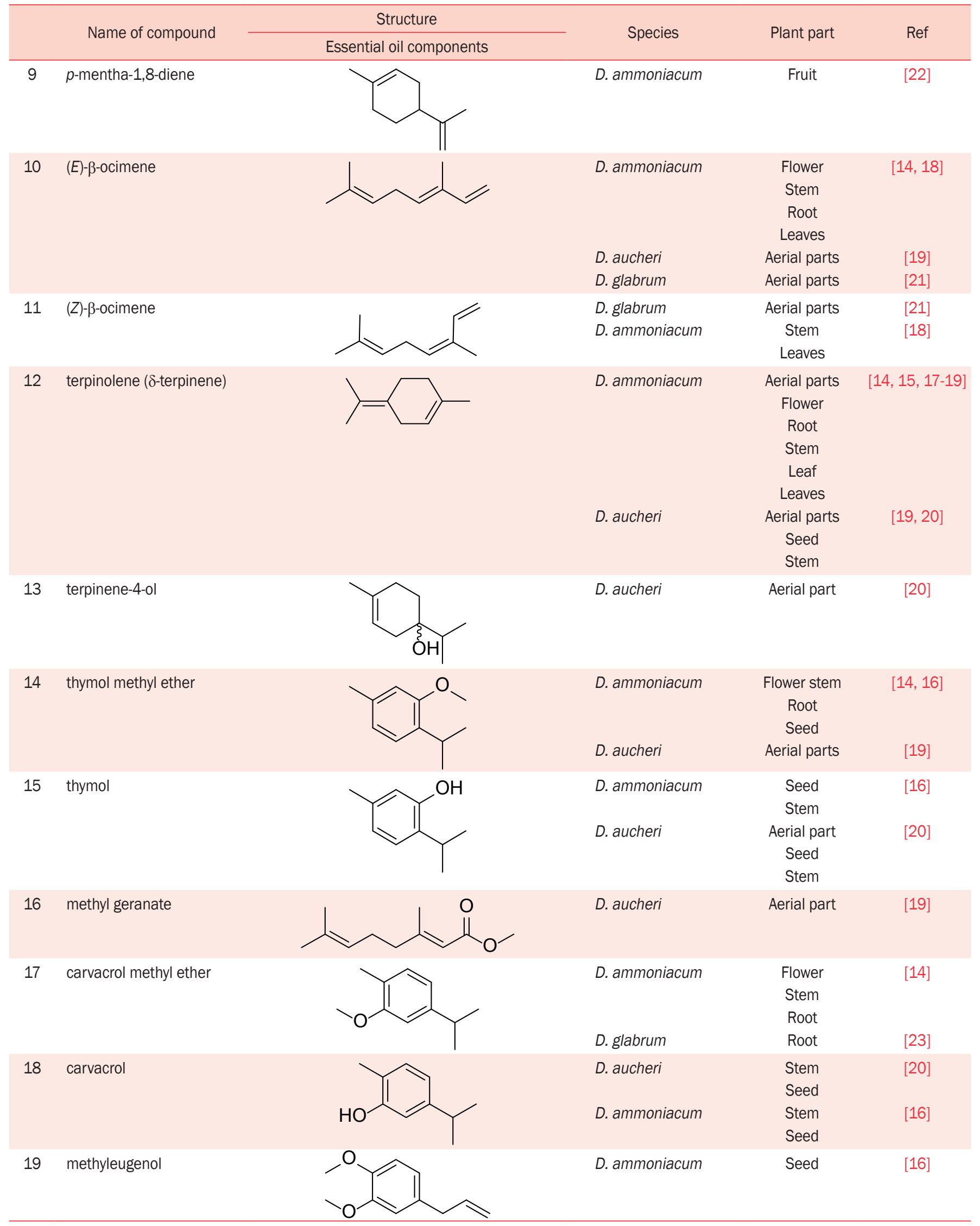


Table 2. Continued 2

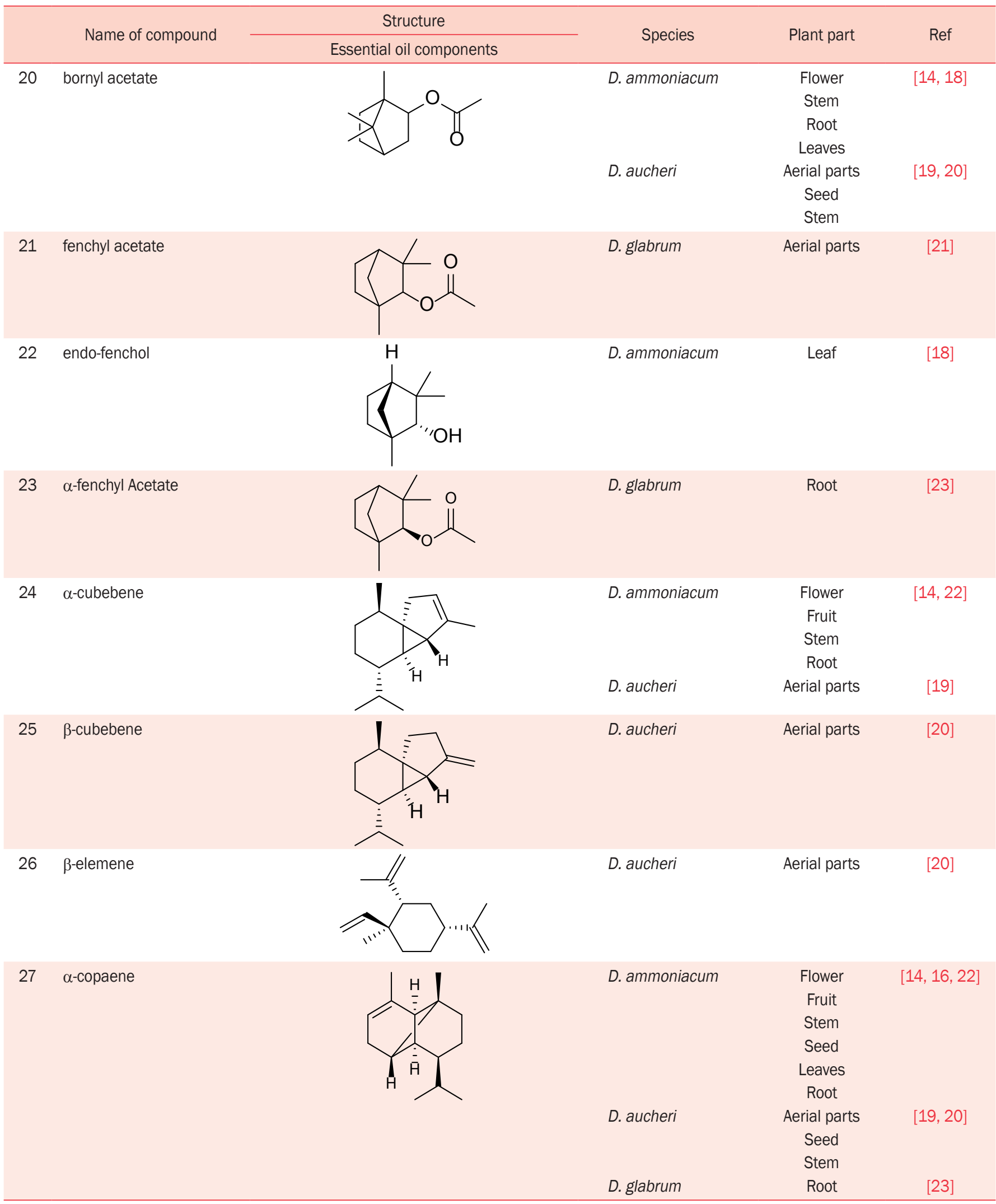


Elaheh Zibaee, et al.

Table 2. Continued 3

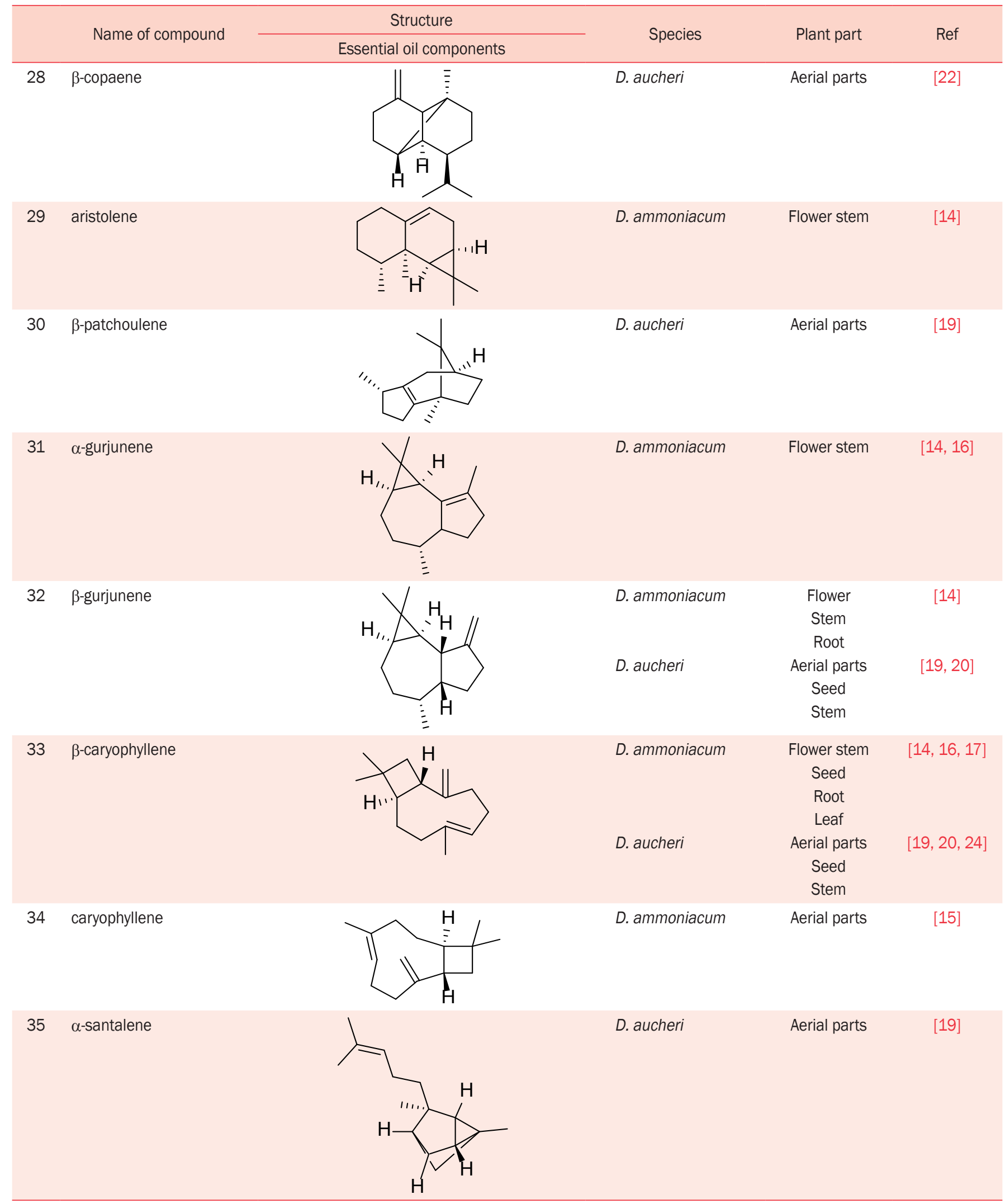


Table 2. Continued 4

\begin{tabular}{|c|c|c|c|c|c|}
\hline & \multirow{2}{*}{ Name of compound } & Structure & \multirow{2}{*}{ Species } & \multirow{2}{*}{ Plant part } & \multirow{2}{*}{ Ref } \\
\hline & & Essential oil components & & & \\
\hline \multirow[t]{2}{*}{36} & aromadendrene & & D. ammoniacum & $\begin{array}{c}\text { Flower stem } \\
\text { Seed } \\
\text { Root }\end{array}$ & {$[14,16]$} \\
\hline & & & D. aucheri & Aerial parts & [19] \\
\hline 37 & $\alpha$-guaiene & & D. ammoniacum & $\begin{array}{c}\text { Flower stem } \\
\text { Root }\end{array}$ & [14] \\
\hline 38 & benzyl butanoate & O & D. ammoniacum & Root & [14] \\
\hline 39 & $\alpha$-himachalene & & D. ammoniacum & $\begin{array}{c}\text { Flower stem } \\
\text { Root }\end{array}$ & [14] \\
\hline 40 & allo-aromadendrene & & D. ammoniacum & $\begin{array}{c}\text { Flower stem } \\
\text { Root }\end{array}$ & [14] \\
\hline 41 & dehydroaromadendrane & & D. ammoniacum & $\begin{array}{c}\text { Flower stem } \\
\text { Root }\end{array}$ & {$[14,16]$} \\
\hline 42 & $\alpha$-amorphene & & D. ammoniacum & $\begin{array}{c}\text { Flower stem } \\
\text { Root }\end{array}$ & [14] \\
\hline & & & D. aucheri & $\begin{array}{l}\text { Seed } \\
\text { Stem }\end{array}$ & {$[20]$} \\
\hline 43 & $\delta$-amorphene & & D. ammoniacum & $\begin{array}{c}\text { Flower stem } \\
\text { Root }\end{array}$ & [14] \\
\hline
\end{tabular}


Elaheh Zibaee, et al.

Table 2. Continued 5

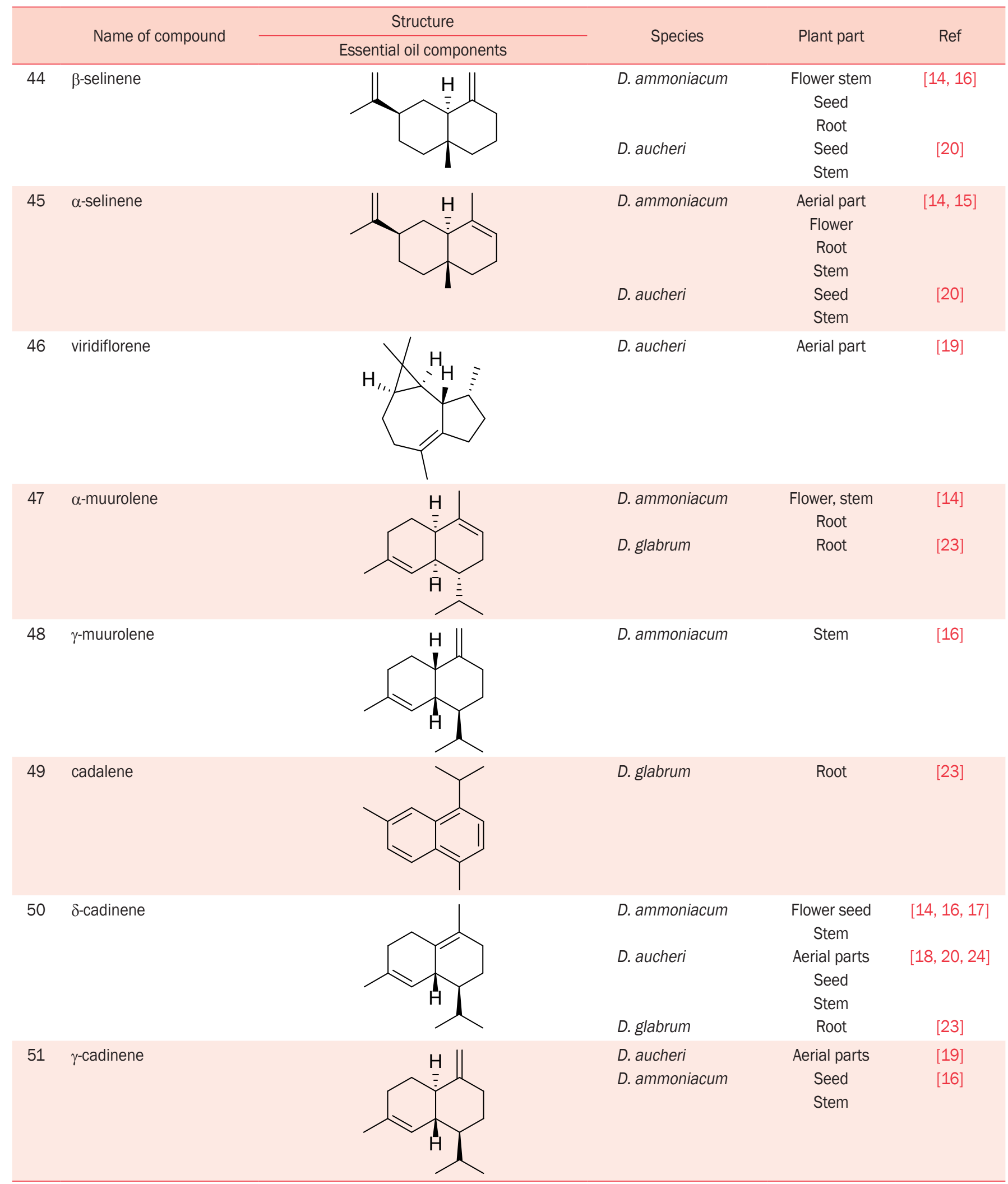


Table 2. Continued 6

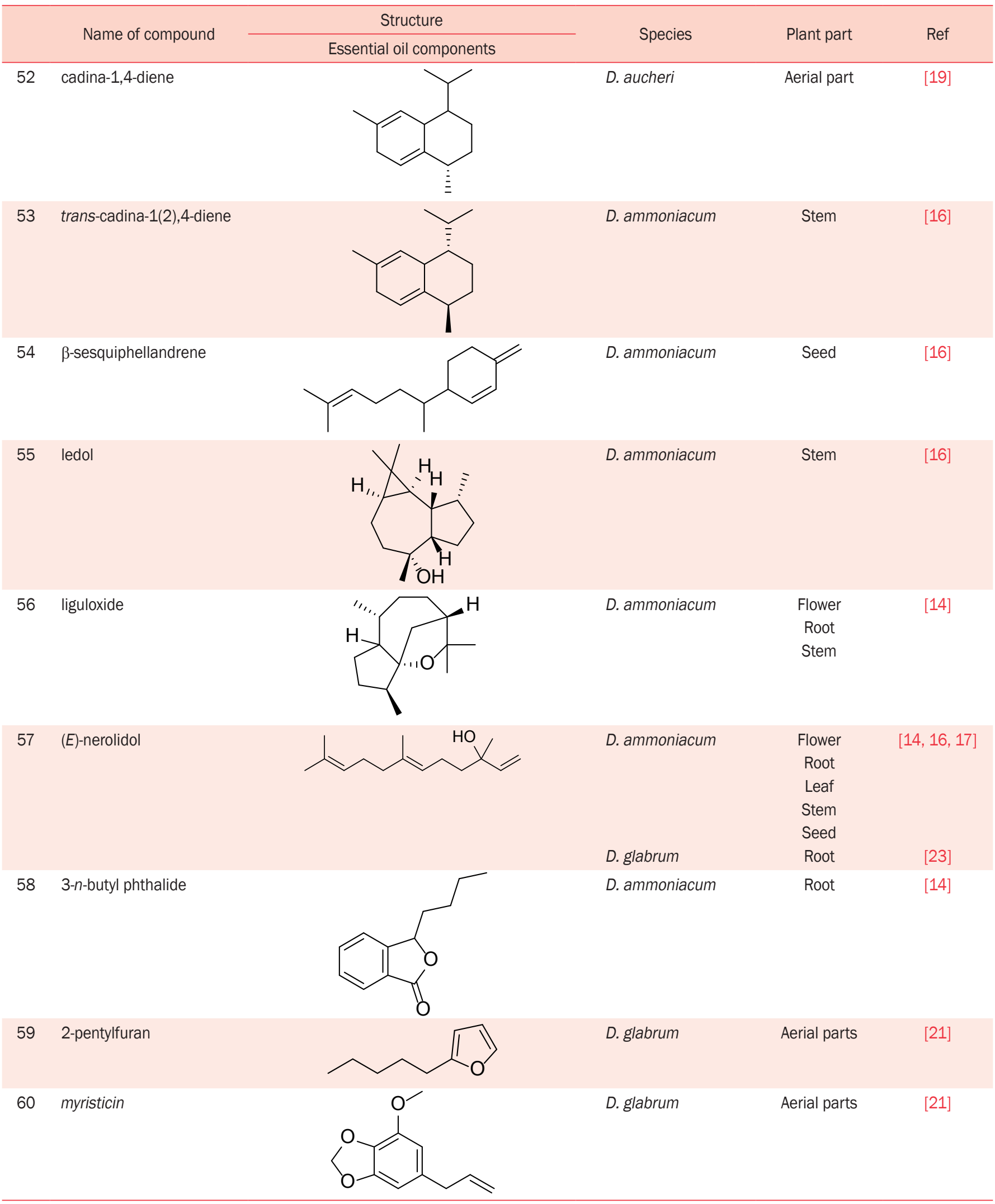


Elaheh Zibaee, et al.

Table 2. Continued 7

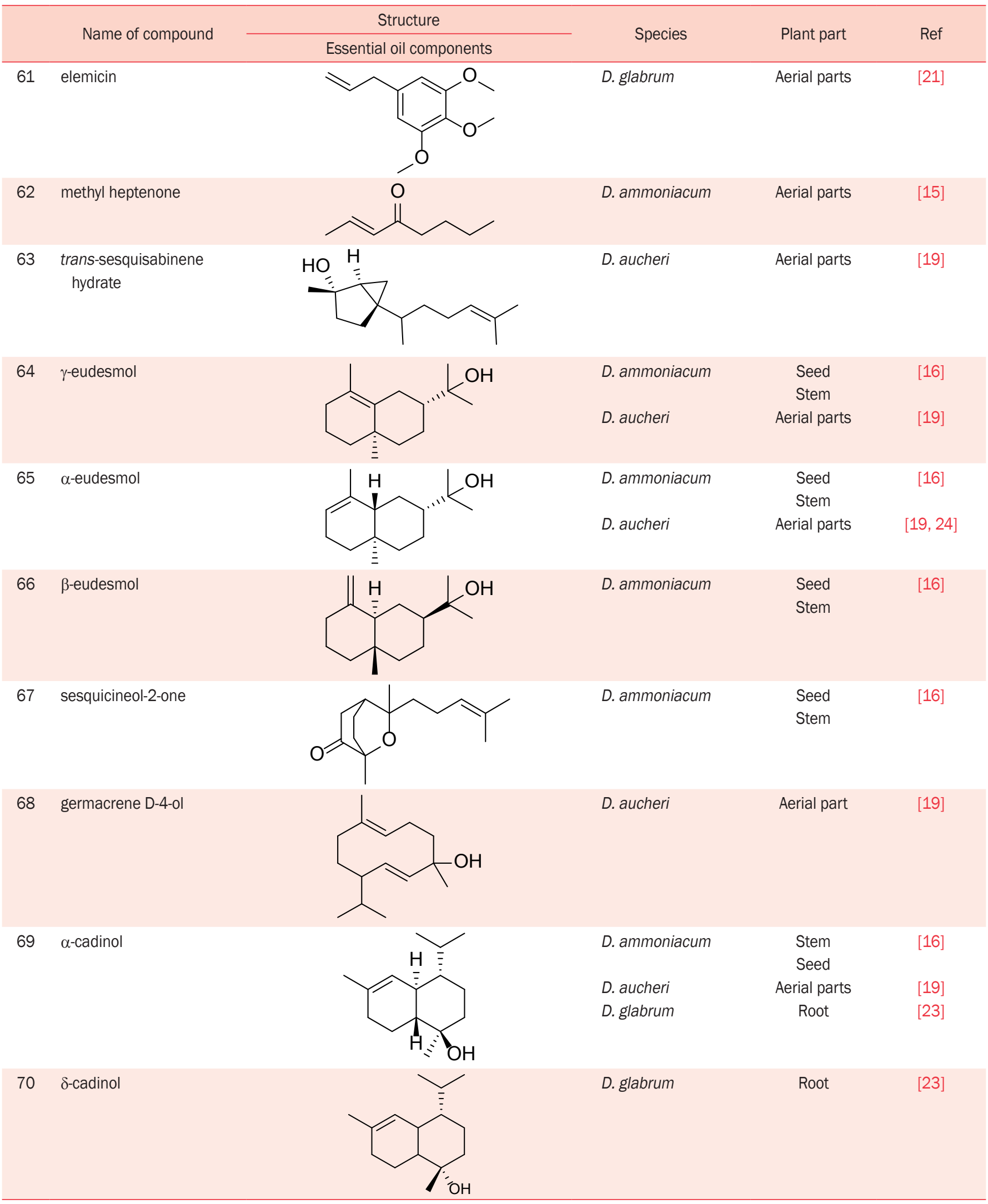


Table 2. Continued 8

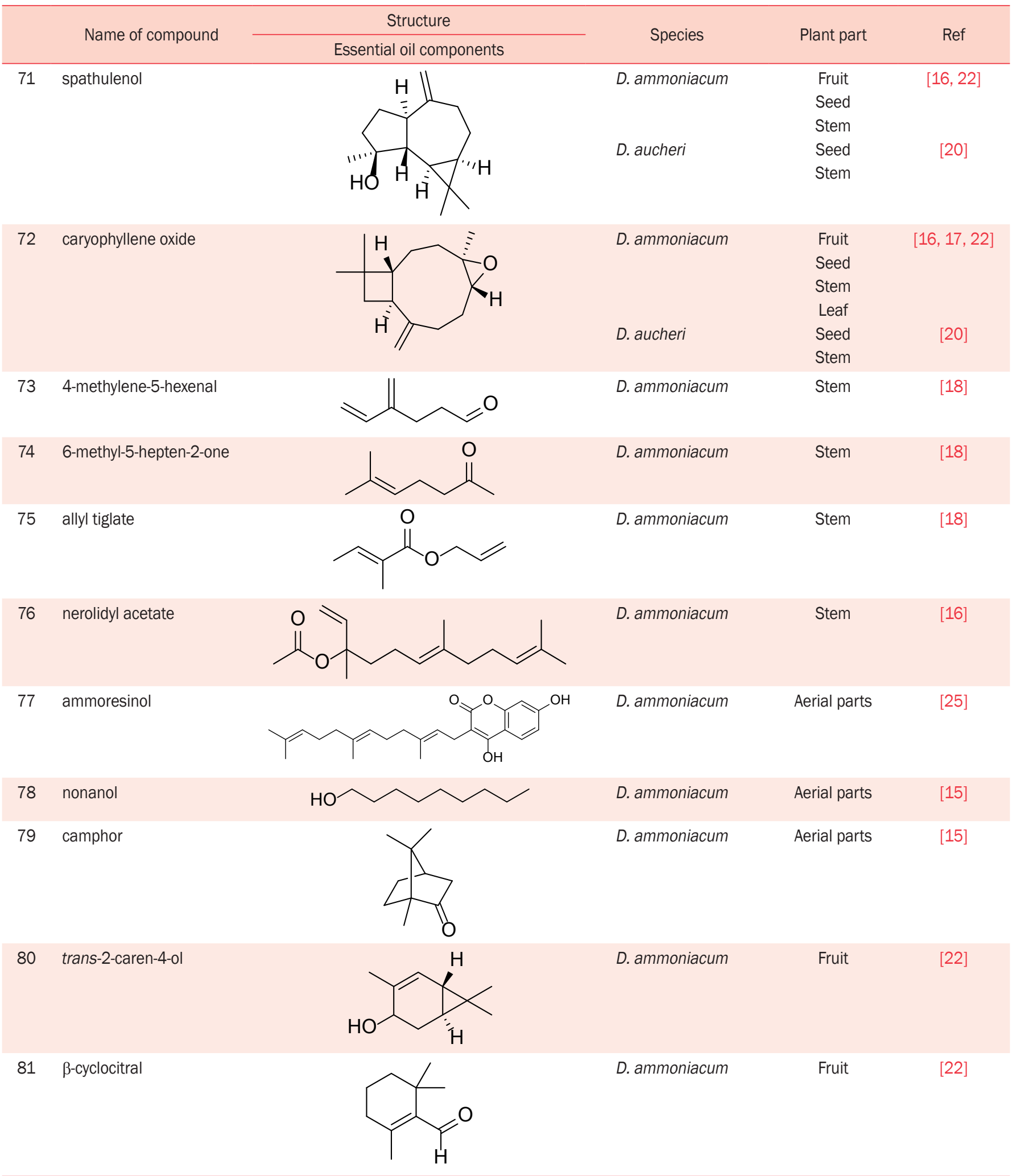


Elaheh Zibaee, et al.

Table 2. Continued 9

\begin{tabular}{|c|c|c|c|c|c|}
\hline & \multirow{2}{*}{ Name of compound } & Structure & \multirow{2}{*}{ Species } & \multirow{2}{*}{ Plant part } & \multirow{2}{*}{ Ref } \\
\hline & & Essential oil components & & & \\
\hline 82 & piperitenone oxide & $\mathrm{O}$ & D. ammoniacum & Fruit & [22] \\
\hline 84 & $\beta$-citronellol & & D. ammoniacum & Aerial parts & [15] \\
\hline 85 & $\beta$-damascenone & & D. ammoniacum & Aerial parts & [15] \\
\hline 86 & cedr-8[15]-ene & & D. ammoniacum & Aerial parts & [15] \\
\hline 87 & cubenol & & $\begin{array}{l}\text { D. aucheri } \\
\text { D. glabrum }\end{array}$ & $\begin{array}{c}\text { Aerial parts } \\
\text { Root }\end{array}$ & $\begin{array}{l}{[19]} \\
{[23]}\end{array}$ \\
\hline 89 & ylangene & & $\begin{array}{l}\text { D. glabrum } \\
\text { D. aucheri }\end{array}$ & $\begin{array}{l}\text { Aerial parts } \\
\text { Seed } \\
\text { Stem }\end{array}$ & $\begin{array}{l}{[21]} \\
{[20]}\end{array}$ \\
\hline 90 & nerylacetone & & D. ammoniacum & Aerial parts & {$[15,17]$} \\
\hline 91 & geranyl acetone & & D. glabrum & $\begin{array}{l}\text { Aerial parts } \\
\text { Root }\end{array}$ & $\begin{array}{l}{[21]} \\
{[23]}\end{array}$ \\
\hline
\end{tabular}


Table 2. Continued 10

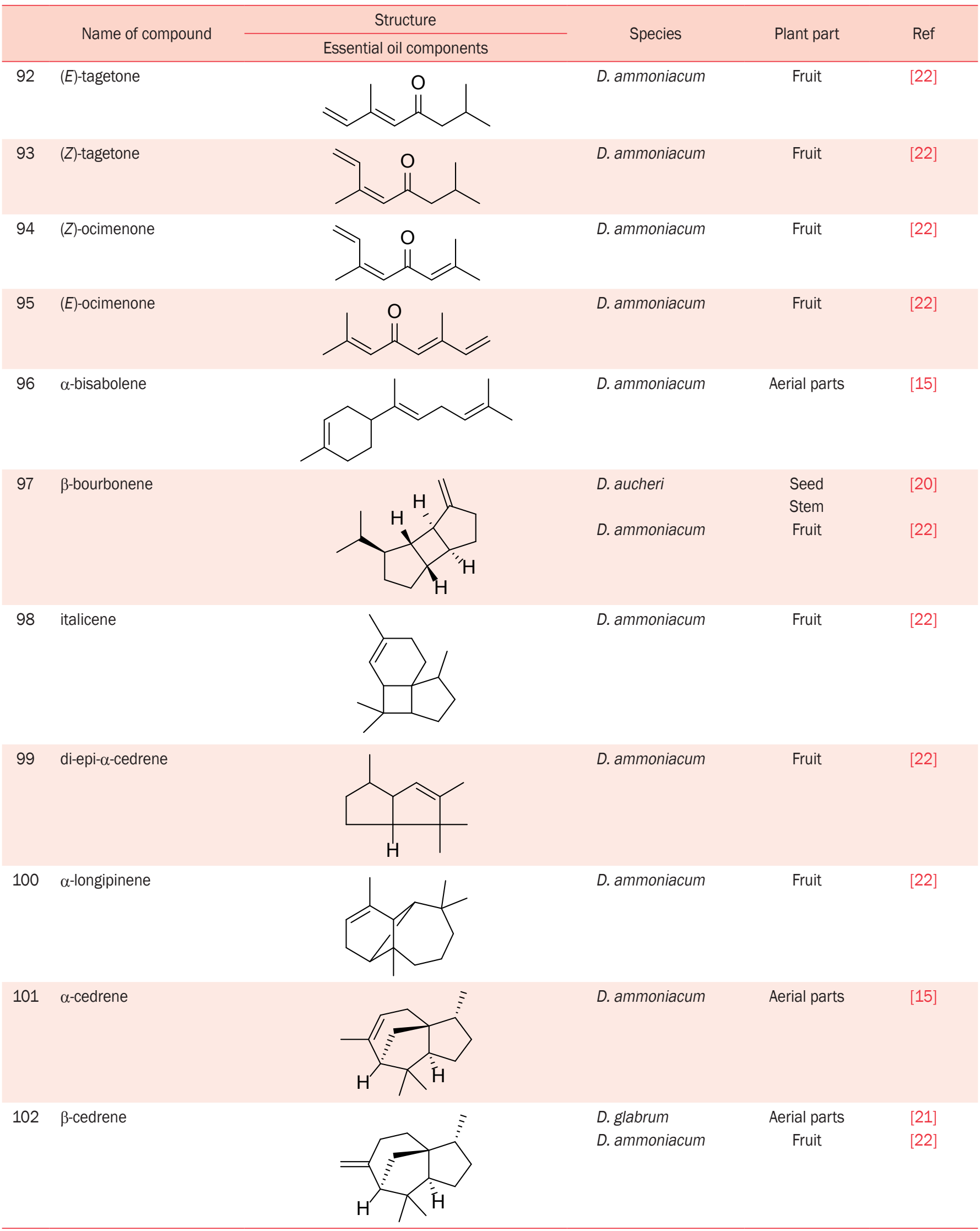


Elaheh Zibaee, et al.

Table 2. Continued 11

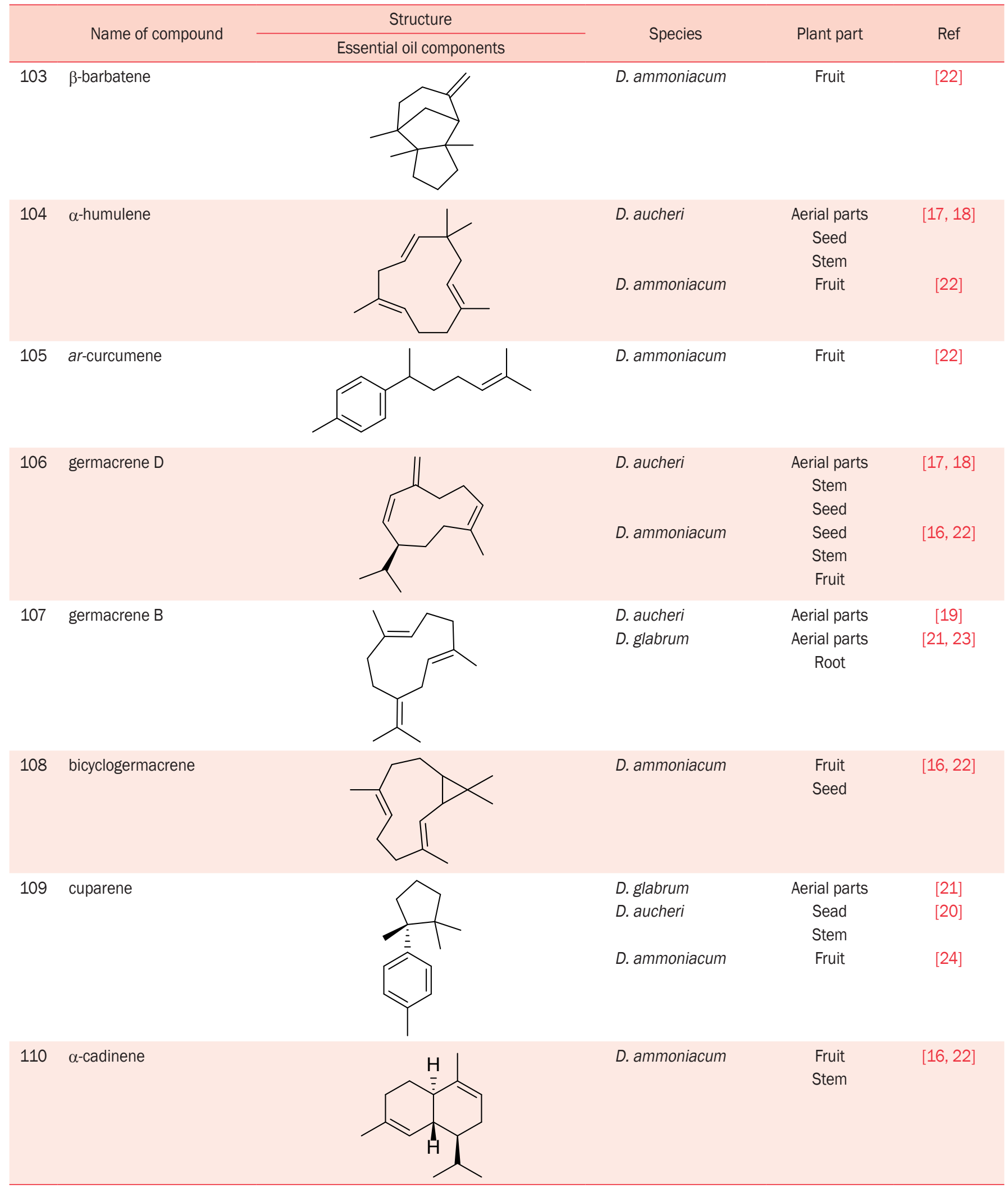


Table 2. Continued 12

\begin{tabular}{|c|c|c|c|c|c|}
\hline & \multirow{2}{*}{ Name of compound } & Structure & \multirow{2}{*}{ Species } & \multirow{2}{*}{ Plant part } & \multirow{2}{*}{ Ref } \\
\hline & & Essential oil components & & & \\
\hline 111 & 2-nonanone & $\mathrm{O}$ & D. ammoniacum & Stem & {$[16]$} \\
\hline 112 & (Z)-hexadec-11-enal & & D. ammoniacum & Stem & {$[16]$} \\
\hline 113 & hexadecanal & & D. ammoniacum & Stem & {$[16]$} \\
\hline 114 & ethyl linoleate & & D. ammoniacum & Stem & {$[16]$} \\
\hline 115 & $(Z, E)$-farnesal & & D. ammoniacum & Aerial parts & [15] \\
\hline 116 & pentadecanal & & D. ammoniacum & Aerial parts & [15] \\
\hline 117 & dodecyl methacrylate & & D. ammoniacum & Aerial parts & [15] \\
\hline 118 & 17-octadecenal & & D. ammoniacum & Aerial parts & [15] \\
\hline 119 & 13-tetradecenal & & D. ammoniacum & Aerial parts & [15] \\
\hline 120 & tetradecanal & & $\begin{array}{l}\text { D. glabrum } \\
\text { D. ammoniacum }\end{array}$ & $\begin{array}{c}\text { Aerial parts } \\
\text { Stem } \\
\text { Seed }\end{array}$ & $\begin{array}{l}{[21]} \\
{[16]}\end{array}$ \\
\hline 121 & trans-sesquilavandulol & & D. ammoniacum & $\begin{array}{l}\text { Seed } \\
\text { Stem }\end{array}$ & {$[16]$} \\
\hline 122 & neophytadiene & & D. ammoniacum & Aerial parts & {$[15,17]$} \\
\hline 123 & neocembren & & D. ammoniacum & Aerial parts & [15] \\
\hline 124 & (E)-5-undecen-3-yne & & D. ammoniacum & Fruit & {$[22]$} \\
\hline 125 & $(Z)-(E)$-farnesene & & D. ammoniacum & Aerial parts & {$[22]$} \\
\hline
\end{tabular}


Elaheh Zibaee, et al.

Table 2. Continued 13

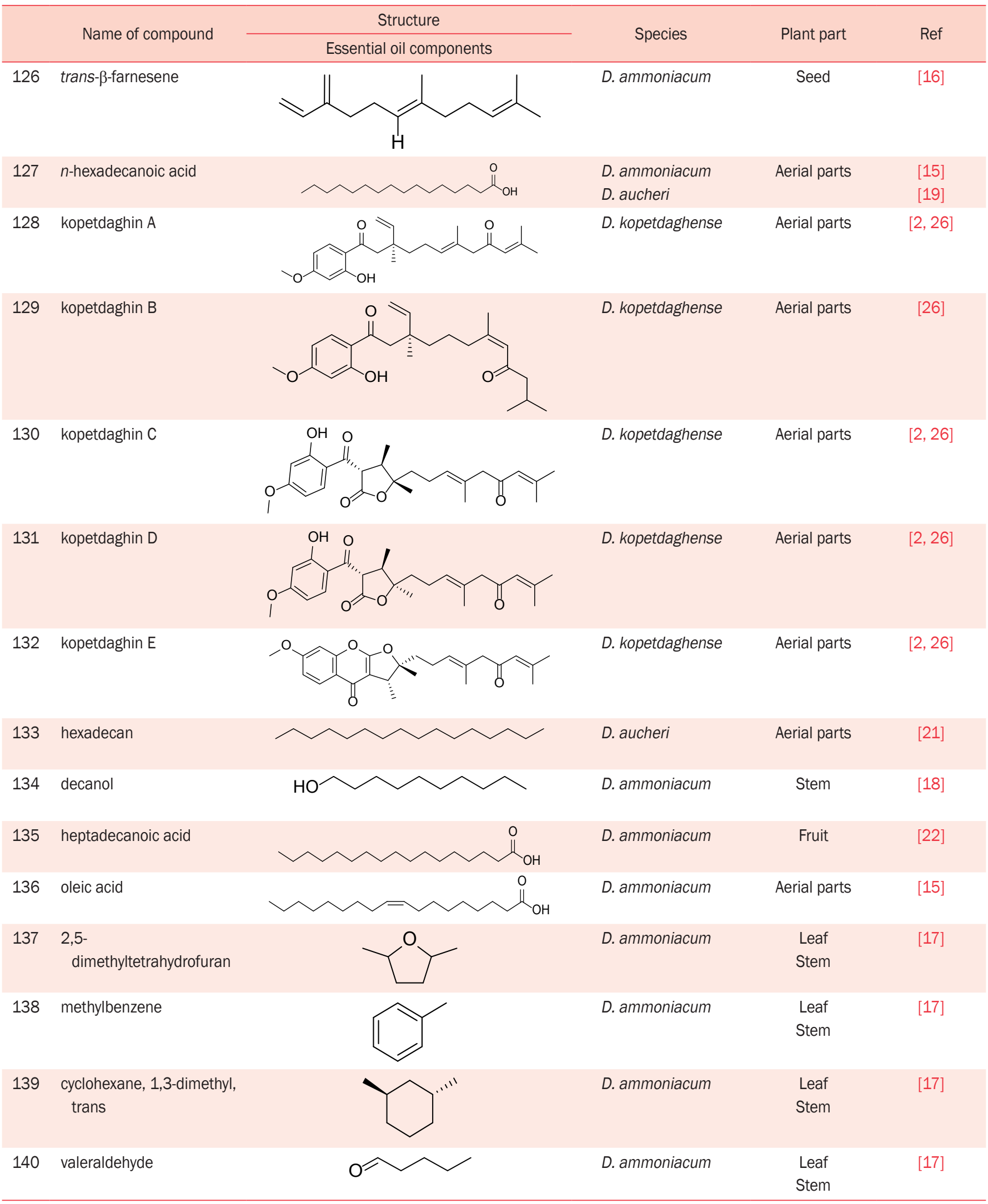


Table 2. Continued 14

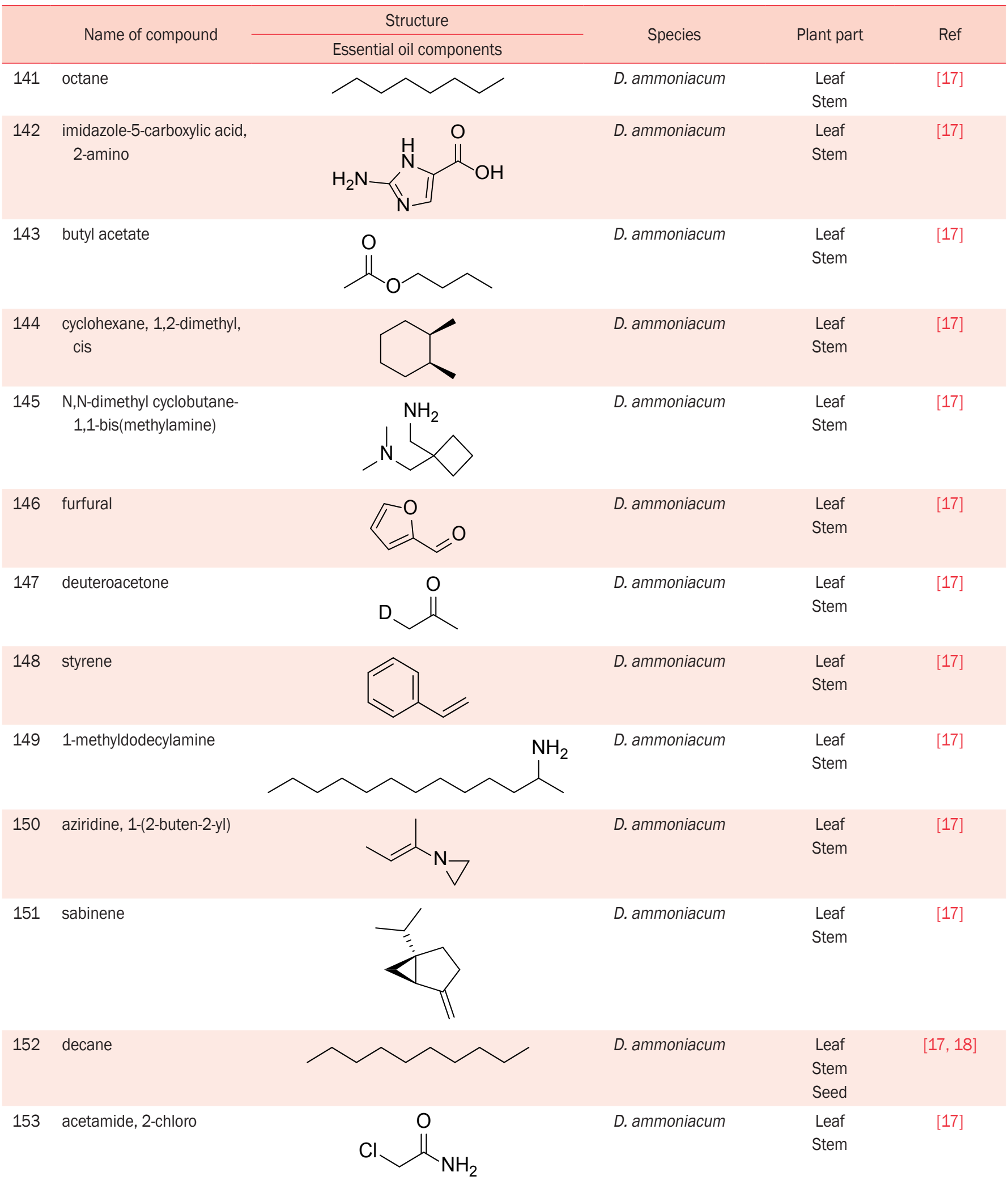


Elaheh Zibaee, et al.

Table 2. Continued 15

\begin{tabular}{|c|c|c|c|c|c|}
\hline & \multirow{2}{*}{ Name of compound } & Structure & \multirow{2}{*}{ Species } & \multirow{2}{*}{ Plant part } & \multirow{2}{*}{ Ref } \\
\hline & & Essential oil components & & & \\
\hline 154 & 2-butylamine & $\mathrm{NH}_{2}$ & D. ammoniacum & $\begin{array}{l}\text { Leaf } \\
\text { Stem }\end{array}$ & {$[17]$} \\
\hline 155 & phenyl acetaldehyde & & D. ammoniacum & $\begin{array}{l}\text { Leaf } \\
\text { Stem }\end{array}$ & [17] \\
\hline 156 & $\begin{array}{l}\text { 2-amino-4- } \\
\text { hydroxypteridine-6- } \\
\text { carboxylic acid }\end{array}$ & & D. ammoniacum & $\begin{array}{l}\text { Leaf } \\
\text { Stem }\end{array}$ & [17] \\
\hline 158 & undecane & & D. ammoniacum & $\begin{array}{l}\text { Leaf } \\
\text { Stem } \\
\text { Seed }\end{array}$ & {$[17,18]$} \\
\hline 159 & limonene oxide & & D. ammoniacum & $\begin{array}{l}\text { Leaf } \\
\text { Stem }\end{array}$ & [17] \\
\hline 162 & 2,6-dimethyl-4-pyrone & & D. ammoniacum & $\begin{array}{l}\text { Leaf } \\
\text { Stem }\end{array}$ & [17] \\
\hline 163 & dodecane & & D. ammoniacum & $\begin{array}{l}\text { Leaf } \\
\text { Stem }\end{array}$ & [17] \\
\hline 164 & 2,4-hexadiene, 3-methyl & & D. ammoniacum & $\begin{array}{l}\text { Leaf } \\
\text { Stem }\end{array}$ & [17] \\
\hline 165 & $\beta$-fenchyl alcohol & & D. ammoniacum & $\begin{array}{l}\text { Leaf } \\
\text { Stem }\end{array}$ & [17] \\
\hline
\end{tabular}


Table 2. Continued 16

\begin{tabular}{|c|c|c|c|c|c|}
\hline & \multirow{2}{*}{ Name of compound } & Structure & \multirow{2}{*}{ Species } & \multirow{2}{*}{ Plant part } & \multirow{2}{*}{ Ref } \\
\hline & & Essential oil components & & & \\
\hline 166 & homarine & & D. ammoniacum & $\begin{array}{l}\text { Leaf } \\
\text { Stem }\end{array}$ & {$[17]$} \\
\hline 167 & $\begin{array}{l}\text { 2-(N,N-dimethyl hydrazino) } \\
\text { cyclohexane carbonitrile }\end{array}$ & & D. ammoniacum & $\begin{array}{l}\text { Leaf } \\
\text { Stem }\end{array}$ & {$[17]$} \\
\hline 168 & phenol, 4-(2-aminopropyl) & & D. ammoniacum & $\begin{array}{l}\text { Leaf } \\
\text { Stem }\end{array}$ & {$[17]$} \\
\hline 169 & $\begin{array}{l}\text { 2-oxo-3-methyl-cis- } \\
\text { perhydro-1,3-benzoxazine }\end{array}$ & & D. ammoniacum & $\begin{array}{l}\text { Leaf } \\
\text { Stem }\end{array}$ & {$[17]$} \\
\hline 170 & trans-carveol & & D. ammoniacum & $\begin{array}{l}\text { Leaf } \\
\text { Stem }\end{array}$ & {$[17]$} \\
\hline 171 & $\begin{array}{l}\text { benzene, (2-fluoro-2- } \\
\text { methoxycyclopropyl) }\end{array}$ & & D. ammoniacum & $\begin{array}{l}\text { Leaf } \\
\text { Stem }\end{array}$ & {$[17]$} \\
\hline 172 & $\begin{array}{l}\text { 2(1H)-naphthalenone, } \\
\text { octahydro-8a-methyl, } \\
\text { trans }\end{array}$ & & D. ammoniacum & $\begin{array}{l}\text { Leaf } \\
\text { Stem }\end{array}$ & {$[17]$} \\
\hline 173 & $p$-methoxyamphetamine & $\mathrm{H}_{2}$ & D. ammoniacum & $\begin{array}{l}\text { Leaf } \\
\text { Stem }\end{array}$ & {$[17]$} \\
\hline 174 & $\begin{array}{l}\text { 2-cyclohexen-1-one, } \\
\text { 2-methyl-5- } \\
\text { (1-methylethenyl) }\end{array}$ & & D. ammoniacum & $\begin{array}{l}\text { Leaf } \\
\text { Stem }\end{array}$ & {$[17]$} \\
\hline 175 & 2-methyl amphetamine & & D. ammoniacum & $\begin{array}{l}\text { Leaf } \\
\text { Stem }\end{array}$ & {$[17]$} \\
\hline 176 & 2-methoxy amphetamine & & D. ammoniacum & $\begin{array}{l}\text { Leaf } \\
\text { Stem }\end{array}$ & {$[17]$} \\
\hline
\end{tabular}


Elaheh Zibaee, et al.

Table 2. Continued 17

\begin{tabular}{|c|c|c|c|c|c|}
\hline & \multirow{2}{*}{ Name of compound } & Structure & \multirow{2}{*}{ Species } & \multirow{2}{*}{ Plant part } & \multirow{2}{*}{ Ref } \\
\hline & & Essential oil components & & & \\
\hline 177 & tridecane & & D. ammoniacum & $\begin{array}{l}\text { Leaf } \\
\text { Stem }\end{array}$ & {$[17]$} \\
\hline & & & D. glabrum & Aerial parts & [21] \\
\hline 178 & $\begin{array}{l}\text { benzenemethanol, alpha- } \\
\text { (1-aminoethyl) }\end{array}$ & & D. ammoniacum & $\begin{array}{l}\text { Leaf } \\
\text { Stem }\end{array}$ & [17] \\
\hline 179 & $\begin{array}{l}\text { naphthalene, 1,2-dihydro- } \\
\text { 1,1,6-trimethyl }\end{array}$ & & D. ammoniacum & $\begin{array}{l}\text { Leaf } \\
\text { Stem }\end{array}$ & [17] \\
\hline 181 & heptadecane & & D. ammoniacum & $\begin{array}{l}\text { Leaf } \\
\text { Stem }\end{array}$ & {$[17]$} \\
\hline 182 & calarene & & D. ammoniacum & $\begin{array}{l}\text { Leaf } \\
\text { Stem }\end{array}$ & [17] \\
\hline 184 & $\begin{array}{l}\text { benzenemethanol, } \\
\text { 3-hydroxy-alpha- } \\
\text { [(methylamino) methyl] }\end{array}$ & & D. ammoniacum & $\begin{array}{l}\text { Leaf } \\
\text { Stem }\end{array}$ & [17] \\
\hline 185 & 1 S-cis-calamenene & & D. ammoniacum & $\begin{array}{l}\text { Leaf } \\
\text { Stem }\end{array}$ & [17] \\
\hline 186 & calamenene & & D. glabrum & Root & [23] \\
\hline
\end{tabular}


Table 2. Continued 18

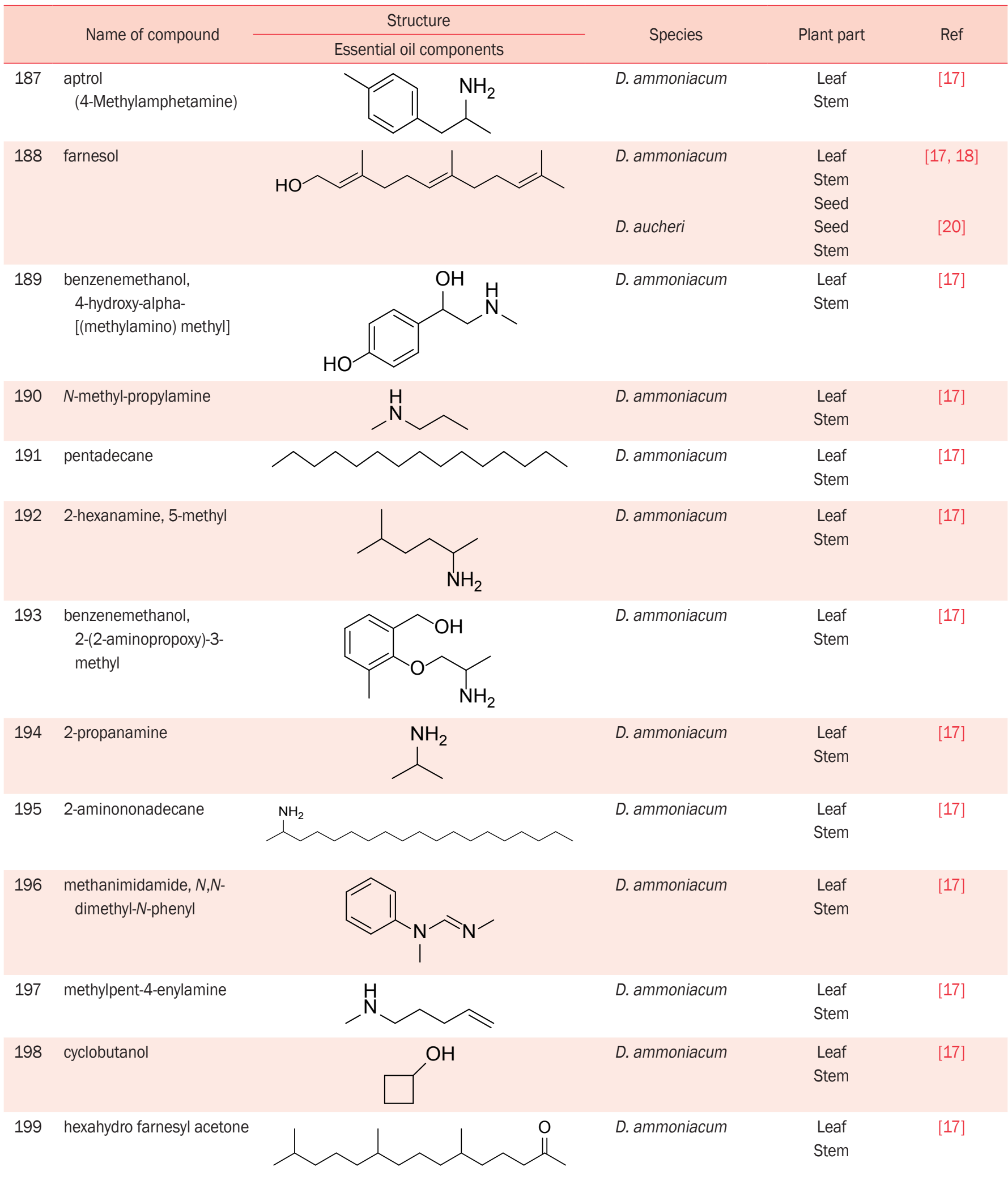


Elaheh Zibaee, et al.

Table 2. Continued 19

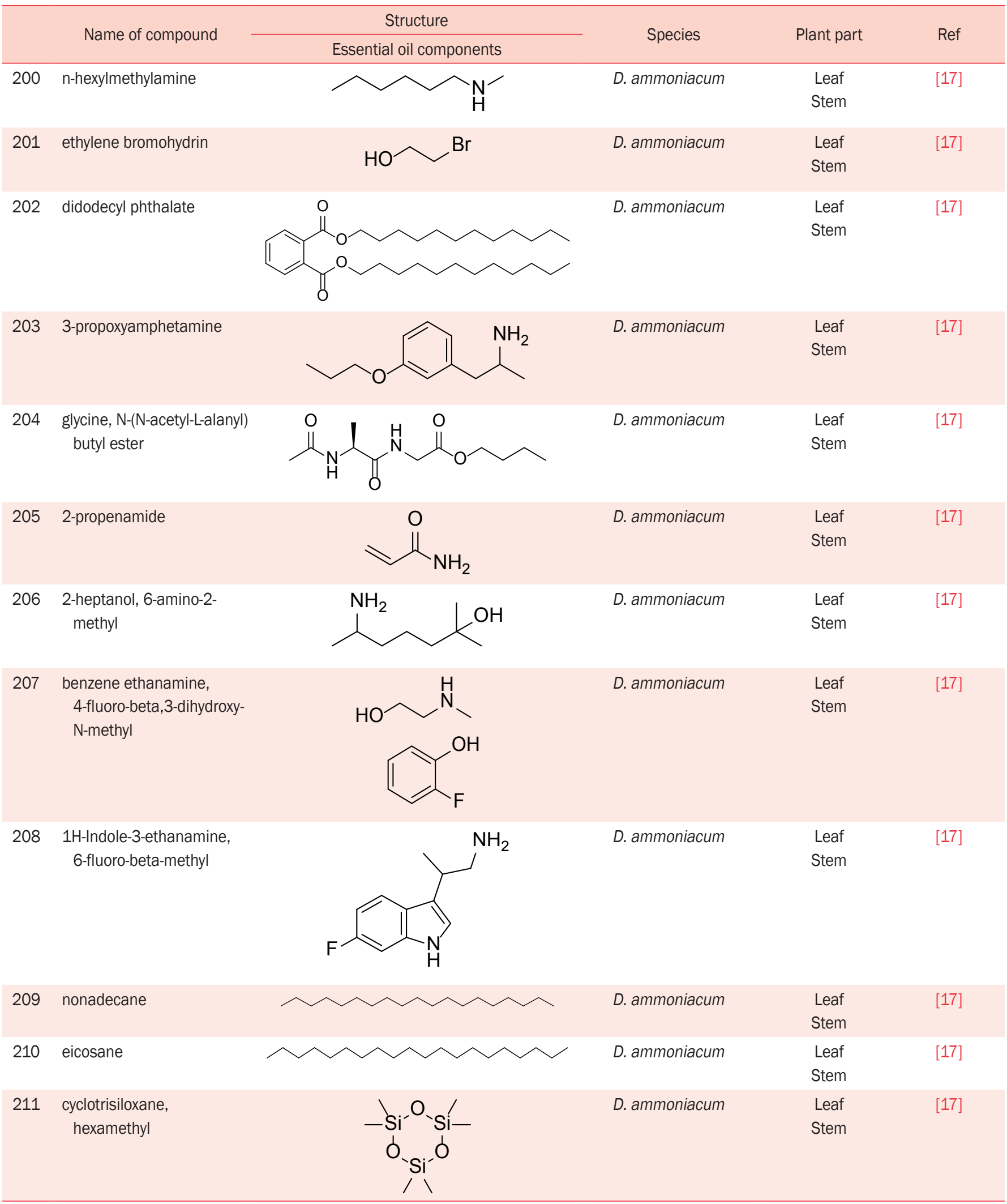


Table 2. Continued 20

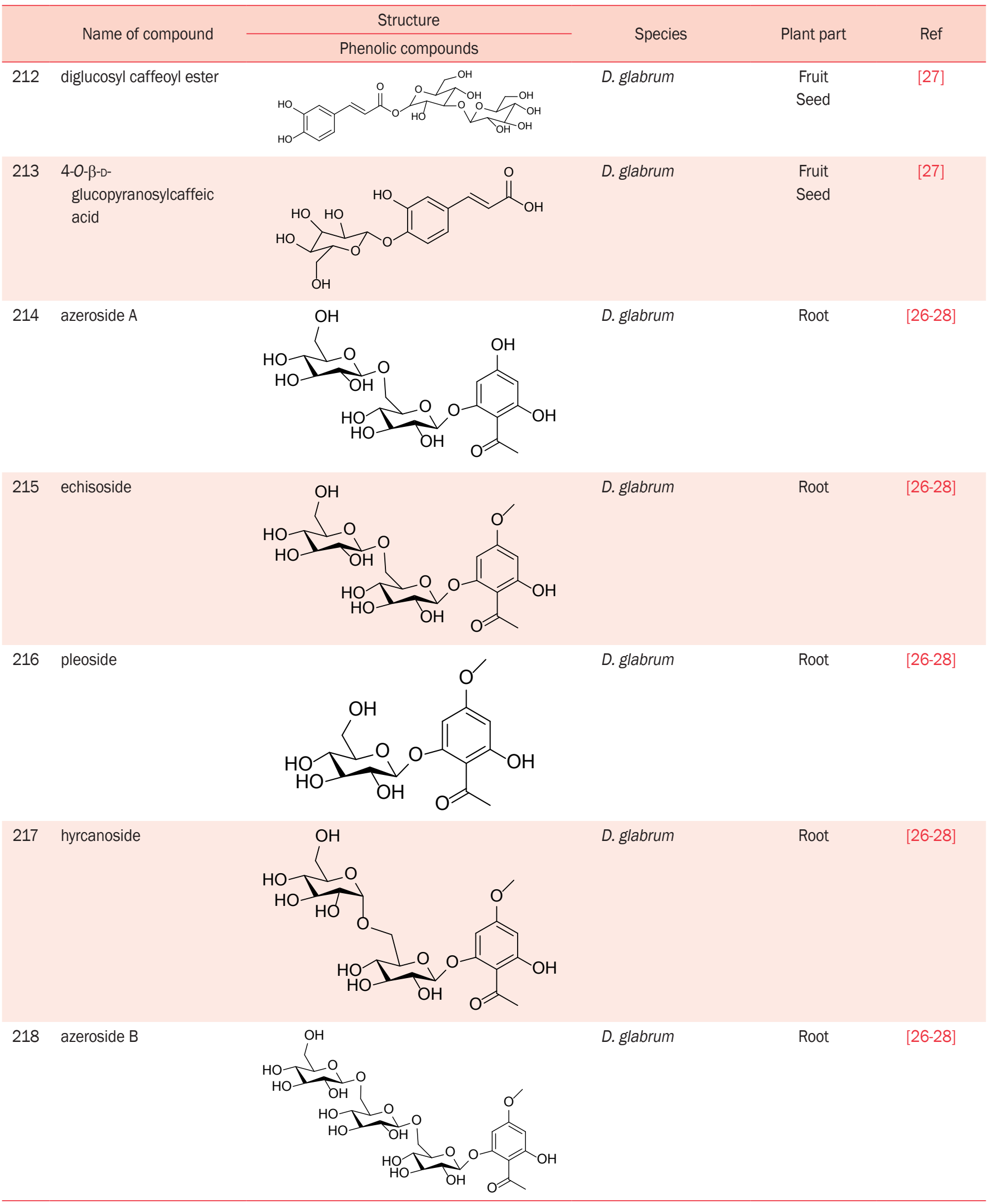


Elaheh Zibaee, et al.

Table 2. Continued 21

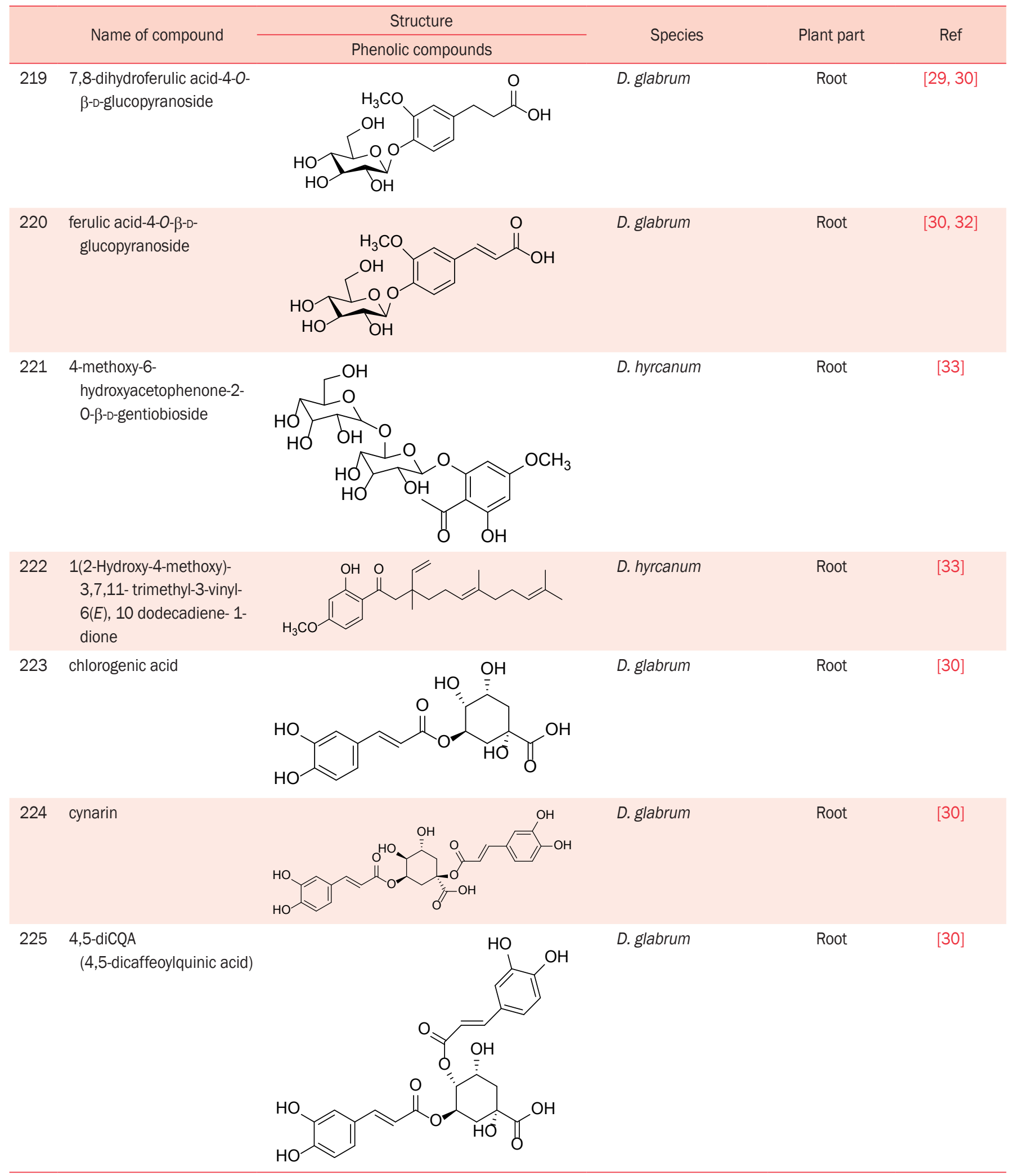


Table 2. Continued 22

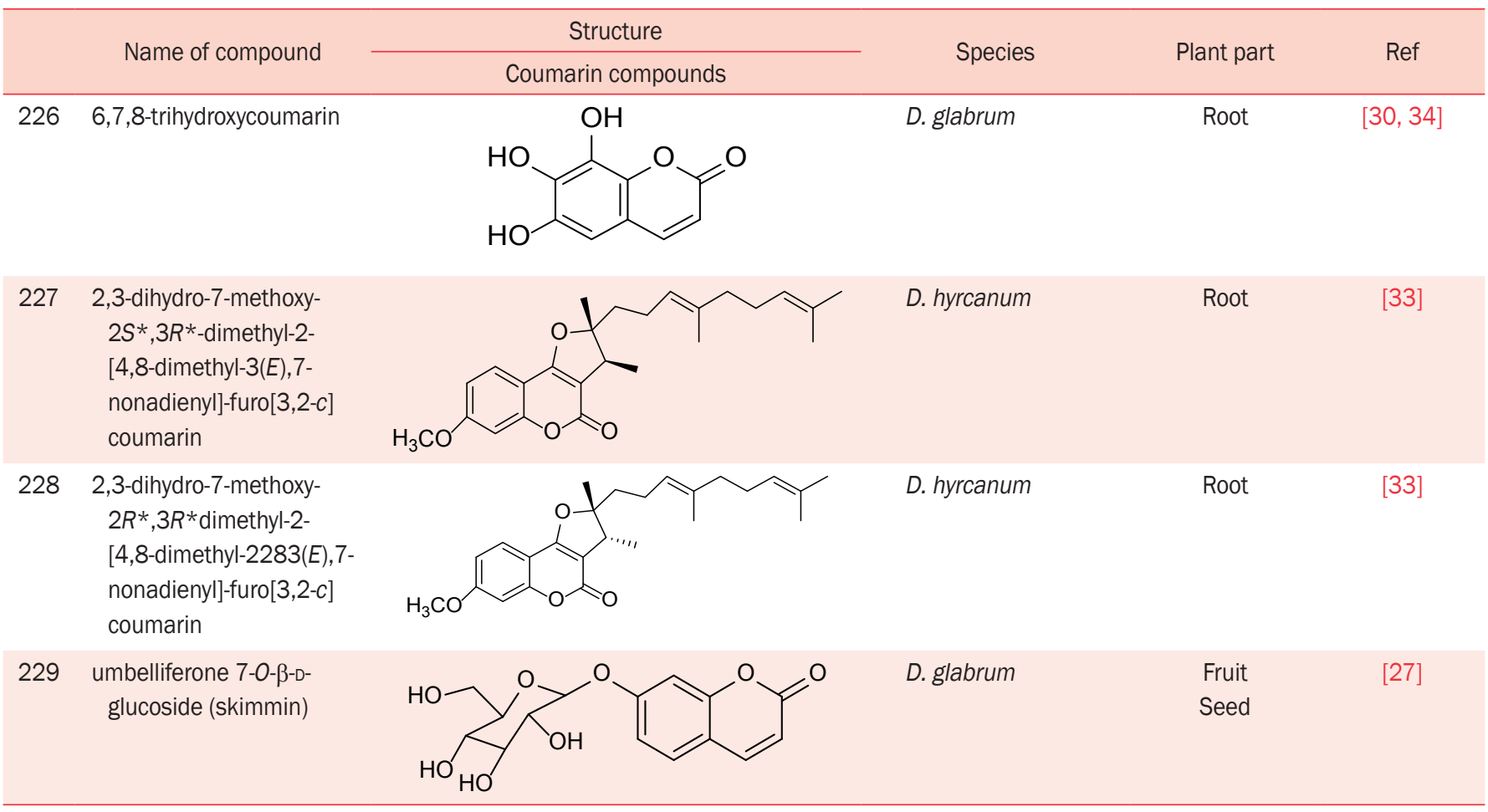

natural treasures within the next few decades.

\section{PHYTOCHEMICAL CONSTITUENTS}

The instrumental analysis was revealed that a range of various compounds were identified in Dorema species, including essential oil structure that made up hydrocarbon molecules and classified as terpenes, alcohols, esters, aldehydes, ketones and phenols, also contain phenolic and coumarin compounds (Table 2). These phytochemicals derived from different parts of Dorema species such as flower, fruit, leaf, stem and root.

\section{ETHNOBOTANICAL USES OF Dorema spp.}

Among 12 species of Dorema, seven have been used in ethnobotany for many decades as a remedy for various human and animal illnesses. These applications of individual Dorema species are shown in Table 3. The most popular species, with the highest number of citations were $D$. ammoniacum and $D$. aucheri.

Dorema ammoniacum has been historically reputed in the folk medicine as a natural remedy for a variety of diseases and known as a rich source of a medicinal gum-resin commonly known as ammoniacum or gum ammoniac. The gum-resin is found in cavities in stems, roots and petioles [5]. In Persia, $D$. ammoniacum (commonly known as Kandal, Vasha and Ushagh.), has a broad spectrum ethnobotanical applications such as anticolic, antifuruncle, expectorant, anthelmintic, emmenagogue agent, anticonvulsant, analgesic, antidote for toxins and laxative. Also, it has been used for treating asthma, bronchitis, stomachache, high blood sugar, infected wounds and infections, acne, abscess, and sciatic pain [6, 35-38].

Western and Indian herbalists recommended it as an antispasmodic, expectorant, diaphoretic and emmenagogue agent and also for treatment of catarrh, asthma, chronic bronchitis and persistent coughing $[39,40]$.

Jordanian herbalist recommended the usage of the resin of $D$. ammoniacum as incense and blood sugar reducer [35].

In Afghanistan, herbal medicine has been used under the name of Unani medicine for centuries. In different parts of Kabul, there are numerous Unani or Loqmani pharmacies locally called "Attari" where Hakims are prescribing the flowers of $D$. ammoniacum for the treatment of diarrhea, peptic ulcer, and other gastric diseases [41].

In Pakistan, D. ammoniacum has been used to treat dysentery and skin diseases by local people particularly in Baluch- 
Elaheh Zibaee, et al.

Table 3. Some of the most important ethnobotanical and traditional uses of Dorema species in different countries

\begin{tabular}{|c|c|c|c|c|c|c|}
\hline No & Dorema species & Vernacular name & Country & Part used & Ethnobotanical and traditional uses & Ref \\
\hline 1 & D. aitchisonii & - & $\begin{array}{l}\text { The former Soviet } \\
\text { Union }\end{array}$ & Shoot & $\begin{array}{l}\text { The water extract from the young shoots is used to } \\
\text { treat diseases of the stomach. }\end{array}$ & [7] \\
\hline \multirow[t]{9}{*}{2} & D. ammoniacum & Kandal & Iran & Gum, root & $\begin{array}{l}\text { Cystitis, digestive, treatment of colic, treatment } \\
\text { of furuncles, expectorant, anthelmintic, } \\
\text { emmenagogue, anticovulsion }\end{array}$ & [6] \\
\hline & & Koma & Iran & Resin & $\begin{array}{l}\text { Antacid, digestive, treatment of colic, furuncles, } \\
\text { expectorant, anthelmintic, emmenagogue and } \\
\text { anticovulsion }\end{array}$ & {$[46]$} \\
\hline & & Anghuzeh & Iran & Latex & Asthma, expectorant, bronchitis, stomachache & {$[37]$} \\
\hline & & Ammoniacum & Jordan & Resin & Incense, blood sugar reduction & {$[35]$} \\
\hline & & Kama eshterk & Iran & Gum & $\begin{array}{l}\text { Healing infected wound and infection, acne and } \\
\text { abscess }\end{array}$ & {$[36]$} \\
\hline & & Ganda ferooza & Afghanistan & Flowers & $\begin{array}{l}\text { Treatment of diarrhea, peptic ulcer and other } \\
\text { gastric diseases }\end{array}$ & {$[41]$} \\
\hline & & Ooshi & Pakistan & Gum & Abortifacient & {$[47]$} \\
\hline & & Oshagh & Iran & Gum & Analgesic, antidote for toxins, laxative, sciatic pain & {$[38]$} \\
\hline & & Kama eshterk & Iran & Gum & $\begin{array}{l}\text { Improvement of infectious wounds and infection, } \\
\text { abscess in sheep and goats }\end{array}$ & {$[48]$} \\
\hline \multirow[t]{5}{*}{3} & D. aucheri & Kal & Iran & Latex & Asthma, expectorant, bronchitis, making gum & {$[37]$} \\
\hline & & Bilhar & Iran & $\begin{array}{l}\text { Young aerial } \\
\text { part }\end{array}$ & $\begin{array}{l}\text { Parasites of digestive system, constipation, use as } \\
\text { vegetable, young stems are pickled }\end{array}$ & {$[12]$} \\
\hline & & $\begin{array}{r}\text { Kama, Eshterk, } \\
\text { Balhareshterk }\end{array}$ & Iran & Gum & Healing infected wound and infection, gasteralgia & {$[36]$} \\
\hline & & $\begin{array}{l}\text { Balhar, Kama, } \\
\text { eshterk }\end{array}$ & Iran & Gum & $\begin{array}{l}\text { Improvement of infectious wounds and infection in } \\
\text { sheep }\end{array}$ & {$[48]$} \\
\hline & & Zou & Iran & Root & Burn healing, cornicide & {$[43]$} \\
\hline 4 & D. aureum & Oshtork & Iran & Gum & Abortion, infection & [49] \\
\hline 5 & D. glabrum & - & Azerbaijan Republic & Gum-resin & $\begin{array}{l}\text { Diuretic and anti-diarrheal agent as well as for } \\
\text { the treatment of bronchitis and catarrh, cure of } \\
\text { cancer }\end{array}$ & {$[15]$} \\
\hline 6 & D. hyrcanum & - & $\begin{array}{l}\text { The former Soviet } \\
\text { Union }\end{array}$ & Resin & $\begin{array}{l}\text { As plasters to stop bleeding and to treat injuries in } \\
\text { horses. }\end{array}$ & [7] \\
\hline 7 & D. sabulosum & Ilyan & Uzbekistan & $\begin{array}{l}\text { Root and } \\
\text { stem }\end{array}$ & $\begin{array}{l}\text { Roots used as diuretic and for head and respiratory } \\
\text { organs. tincture from green stem used as a } \\
\text { remedy for head and heart illnesses. }\end{array}$ & {$[45]$} \\
\hline
\end{tabular}

istan province [42].

In Iranian folk medicine, D. aucheri is used against asthma, bronchitis, parasites of digestive system, constipation, burns and infected wounds young leaves and branches are used for making a locally popular pickle called "Bilhar Pickle" and soups $[12,36,37,43]$.

Based on the folk beliefs of Azerbaijan and Armenian people, Dorema species can treat many abnormalities especially catarrh, bronchitis and diarrhea and also can act as diuretic [44]. Besides, they use D. glabrum for many illnesses especially various types of cancer [23].

In former times, some Dorema species were consumed in the former Soviet Union. The resins of $D$. hyrcanum were used by the local population as plasters to stop bleeding and to treat injuries in horses. The water extract from the young shoots of $D$. aitchisonii is used to treat diseases of the stomach [7]. 
In Uzbekistan, milky latex from the roots of $D$. sabulosum is used as diuretic and for head and respiratory organs. Tincture from green stem is useful for head and heart diseases [45].

\section{NATURE OF D. ammoniacum DESCRIBED IN ITM}

In all of ITM literatures the Mizaj (temperament) of Dorema is mentioned as hot and dry [50-57]. Avicenna and other ITM scientists believed that Dorema is a purgative (for bile, yellow bile, and phlegm), resolvent (mohallel), desiccant, deobstruent (mofatteh), laxativeand attractive agent [50-57].

Droma ammoniacum has been known as a rich source of ammoniacum or gum ammoniac. This medicinal gum-resin has been described by Dioscorides as following:

"It is also called "agasyllon", "criotheos", or "heliastrus", and the Romans call it "gutta". Its smell is similar to castor odor with bitter taste.it has a good color, is not woody, without stones, similar to frankincense in little clots, clear and thick, without filth, this type is called "thrausma" and its earthy or stony kind is called "phurama" [51].

\section{USES OF D. ammoniacum IN ITM}

According to ITM texts, $D$. ammoniacum, $D$. aucheri and $D$. aureum are the most usable species with similar effects, so in the following sections, we have only mentioned and categorized D. ammoniacum medicinal activities on target organs according to the text books, listed in Table 4.

\section{Liver and spleen}

One of the most traditional uses of Dorema is in liver and spleen disorders.

The liniment of $D$. ammoniacum with vinegar (acetum) on the skin of spleen and liver is an effective remedy for hepatitis, splenitis and sclerosis of liver and stiffness of spleen. Oral administration of this combination has the same effect for mentioned disease. Besides, Dorema has been used for treating liver obstructions $[52,55,57]$.

\section{Gastrointestinal system}

In the most of the investigated ITM books, Dorema spp. has been recommended as an anthelmintic agent against gastrointestinal worms and tinea $[52,54,55,57]$, as a laxative for treating constipation [56] and as a purgative agent for cleansing the stomach from the phlegmatic excreta $[53,58]$. In addition, many ITM scientists believed that Dorema spp. treats hemorrhoids and anal disorders because of its deobstuent effect on the rectal veins $[54,57]$.

\section{Upper respiratory tract}

The therapeutic properties of Dorema spp. on theupper respiratory tract are paid attention by many scientists in ITM. They described it as a good remedy for orthopnea, dyspnea, diphtheria and specifically asthma. Ibn Nafis Qarashi in his book (Al-Mujaz fi'l-Tibb) recommended that a linctus of Dorema with honey or mucilage of barley is useful for the mentioned diseases, as well as scrofula [55]. This mixture is frequently mentioned in other ITM books such as Makhzan al-Adwiah,

Table 4. Major ITM books and their authors that described medicinal properties of Dorema spp.

\begin{tabular}{|c|c|c|c|}
\hline Book & Language & Author & Living period \\
\hline Al-Qânun fi al-Tibbe & Arabic & Ibn Sina & 980-1037 A.D. \\
\hline Zakhireh khârazmshâhi & Persian & Jorjâni & 1042-1136 A.D. \\
\hline Al-Aghrâz al-Tibbe wa al-Mabâhethi al-Alâiiiah & Persian & Jorjâni & 1042-1136 A.D. \\
\hline Al-Jâmee le Mofradât al-Adwiah wa al-Aghziah & Arabic & Ibn Al-Baytâr & 1193-1248 A.D. \\
\hline Tadhkirat Oli al-Albâb wa al-Jâme le al-Ajb al-Ujâb & Arabic & Antaki & 1535-1599 A.D. \\
\hline Hadiqat al-Azhâr fi Mâhiyyat al-ushb wa al-uqqâr & Arabic & Ghasani & 1547-1611 A.D. \\
\hline Al-Mujaz fi'l-Tibb & Arabic & Ibn Nafis Qarshi & 1213- 1288 A.D. \\
\hline Tohfah al-Momenin & Persian & Husseini Tonekaboni & $17^{\text {th }}$ century \\
\hline Makhzan al-Adwiah & Persian & Aqili Khorasani & $18^{\text {th }}$ century \\
\hline
\end{tabular}


Elaheh Zibaee, et al.

Table 5. In vitro studies of Dorema spp.

\begin{tabular}{|c|c|c|c|c|c|c|}
\hline Species & Part used & Type of extraction & Activity & Tested pathogen/cell & Result(s) & Ref \\
\hline D. aucheri & Gum & $\begin{array}{l}\text { Dichloromethane, } \\
\text { methanol extract }\end{array}$ & Anti-microbial activity & $\begin{array}{l}\text { E. coli, K. pneumoniae, } \\
\text { P. aeruginosa, } \\
\text { C. albicans }\end{array}$ & MIC: 20 and $40 \mathrm{mg} / \mathrm{mL}$ & [59] \\
\hline D. ammoniacum & Oleogum resin & $\begin{array}{l}\text { Dichloromethane } \\
\text { and methanol } \\
\text { extract }\end{array}$ & $\begin{array}{l}\text { Anti-bacterial and } \\
\text { anti-fungal }\end{array}$ & G+ and G- & C: 500 and $1000 \mu \mathrm{g} / \mathrm{mL}$ & [60] \\
\hline D. ammoniacum & Aerial parts & Methanol extract & Anti-microbial activity & $\begin{array}{l}\text { S. aureus } \\
\text { Enterococcus sp. } \\
\text { C. albicans } \\
\text { E. coli }\end{array}$ & MIC:78 $\mu \mathrm{g} / \mathrm{mL}$ & [61] \\
\hline D. aucheri & Aerial parts & Methanol extract & $\begin{array}{l}\text { Anti-microbial and } \\
\text { anti-oxidative }\end{array}$ & $\begin{array}{l}\text { B. cereus, S. aureus, } \\
\text { E. coli } \\
\text { S. enterica }\end{array}$ & MIC: $10-50 \mathrm{mg} / \mathrm{mL}$ & [62] \\
\hline D. ammoniacum & Ripe fruit & Essential oil & Anti-microbial activity & $\begin{array}{l}\text { B. subtilis } \\
\text { S. epidermidis }\end{array}$ & MIC: $3.75 \mathrm{mg} / \mathrm{mL}$ & [22] \\
\hline D. aucheri & Leaf & Ethanol extract & Anti-bacterial activity & $\begin{array}{l}\text { S. pyogenes } \\
\text { P. aeruginosa }\end{array}$ & $\begin{array}{l}\mathrm{MIC} \text { and } \mathrm{MBC} \text {. } \\
30 \text { and } 40 \mathrm{mg} / \mathrm{mL}\end{array}$ & [63] \\
\hline D. aucheri & Aerial parts & $\begin{array}{l}\text { Hydro-alcoholic } \\
\text { extract }\end{array}$ & Cytotoxicity & $\begin{array}{l}\text { Artemia urmiana larve } \\
\text { (lethaling brine shrimp) }\end{array}$ & $\mathrm{LC}_{50} 76.50 \pm 0.60 \mu \mathrm{g} / \mathrm{mL}$ & [64] \\
\hline D. kopetdaghense & Aerial parts & $\begin{array}{l}\text { Kopetdaghins } \mathrm{A}, \mathrm{C} \\
\text { and } \mathrm{E}\end{array}$ & $\begin{array}{l}\text { Anti-inflammatory } \\
\text { effect }\end{array}$ & $\begin{array}{l}\text { J774A.1 murine } \\
\text { macrophages }\end{array}$ & $\begin{array}{l}\mathrm{IC}_{50}: 474.1 \pm 0.9 \\
496.4 \pm 0.7 \text { and } \\
514.3 \pm 0.4 \mu \mathrm{g} / \mathrm{mL}\end{array}$ & [2] \\
\hline D. aucheri & Aerial parts & $\begin{array}{l}\text { Water/ethanol } \\
\text { extract }\end{array}$ & Anti-coccidial effects & Fecal samples & $\begin{array}{l}\text { lowest (1.60) and the } \\
\text { highest body weight } \\
\text { (1.75) FCR }\end{array}$ & [65] \\
\hline D. aucheri & Roots & EtOAc extract & $\begin{array}{l}\text { No scavenging, } \\
\text { and anti-bacterial } \\
\text { activities }\end{array}$ & $\begin{array}{l}\text { E. coli, } \\
\text { S. flexneri } \\
\text { S. aureus } \\
\text { B. subtilis }\end{array}$ & $\begin{array}{l}\text { MIC: } 0.156, \text { E. coli } \\
\text { IC }_{50}: 113.74 \pm 0.21 \\
\text { and } 597.64 \pm 0.33 \mu \mathrm{g} / \mathrm{mL}\end{array}$ & [66] \\
\hline D. aucheri & Aerial parts & $\begin{array}{l}\text { Hydroalcoholic and } \\
\text { aqueous extracts }\end{array}$ & $\begin{array}{r}\text { Genotoxicity } \\
\text { evaluation }\end{array}$ & HepG2 cell line & $\begin{array}{l}\text { Genotoxic effect: } \\
500 \mu \mathrm{g} / \mathrm{mL}\end{array}$ & [67] \\
\hline D. glabrum & Root & $n$-hexane extracts & $\begin{array}{l}\text { Apoptosis and cell } \\
\text { cycle arrest }\end{array}$ & Cancer cells & $\mathrm{IC}_{50}: 6.4,4.6 \mu \mathrm{g} / \mathrm{mL}$ & [68] \\
\hline D. glabrum & Seed & Methanol extracts & Apoptotic effects & WEHI-164 cells & $\begin{array}{l}\text { Apoptosis and } \\
\text { antiproliferative } \\
\text { properties }\end{array}$ & [69] \\
\hline D. ammoniacum & Oleogum resin & Methanol extracts & Cytotoxic effects & Saccaromyces cerevisiae & $\mathrm{IC}_{12}: 3.14 \mathrm{mg} / \mathrm{mL}$ & [70] \\
\hline D. aucheri & Aerial part & Methanol extracts & Cytotoxic activity & $\begin{array}{l}\text { HepG2 and } \\
\text { A549 cells }\end{array}$ & $\mathrm{IC}_{50}: 20.09,48.65 \mu \mathrm{g} / \mathrm{mL}$ & {$[71]$} \\
\hline D. glabrum & Seed & Methanol extracts & Cytotoxic effects & $\begin{array}{l}\text { WEHI-164 cells, mouse } \\
\text { Fibrosarcoma cell line } \\
\text { and L929 normal cells }\end{array}$ & $\begin{array}{l}\mathrm{IC}_{50}: 50 \mu \mathrm{g} / \mathrm{mL} \text { in } \\
36 \text { hours }\end{array}$ & [72] \\
\hline D. glabrum & Seeds & Methanol extract & $\begin{array}{l}\text { Geno/cytotoxicty and } \\
\text { apoptotic }\end{array}$ & CAOV-4 cells & $\begin{array}{c}\mathrm{IC}_{50}: 99.7,87.3,70.03 \\
\mu \mathrm{g} / \mathrm{mL} \text { at } 48 \mathrm{~h}\end{array}$ & [73] \\
\hline D. glabrum & Roots & Essential oil & $\begin{array}{l}\text { Free radical } \\
\text { scavenging }\end{array}$ & DPPH assay & $\mathrm{RC}_{50}: 2.24 \mathrm{mg} / \mathrm{mL}$ & [23] \\
\hline D. glabrum & Aerial parts & Methanol fraction & Antioxidant & DPPH assay & $\mathrm{IC}_{50}: 53.3 \pm 4.7 \mu \mathrm{g} / \mathrm{mL}$ & [21] \\
\hline
\end{tabular}


Tohfah al-Momeninand etc. [52, 54, 55, 57]. The above mixture was used for purgation of the lungs from phlegmatic humors, too $[52,57]$.

\section{Eyes}

In all ITM records, treating ocular problems by Dorema preparations have been reported. A collyrium (kohl) of Dorema was used for improving the thickness of eyelids, treating trachoma, leukoma (opacity of the cornea) ophthalmia and stye $[52,55,57,58]$. Dorema is an effective remedy for moisturizing roughness of eyelids $[52,55,58]$. In addition, it dries up eye moisture $[52,55,57]$.

\section{Central nervous systems}

Due to descanting effects of Dorema, it was described as a purgation agent to clean the brain from phlegm and other humors [52]. Taking a combination of Dorema with honey or beer is a useful remedy for epilepsy and insensibility (numbness) spasms $[52,57]$. Also gurgling a warm watery solution of the plant is suitable for cleaning the brain from waste phlegm and humors, dizziness, paralysis, facial paralysis and vertigo [52].

\section{Genitourinary system}

Dorema spp. has diuretic and emmenagogic properties, therefore, it has been used as a treatment for dysuria and as an abortifacient agent $[52,54,55]$. Dorema preparations have also been reported to be useful for nephrolith and cystolith [52, 57]. Some ITM scientists have recommended it as a remedy for the hardness of testicles and orchitis as well [52].

\section{Skin}

Dorema has been described to have the property of improving complexion; Therefore, it was particularly used for vitiligo, melisma and freckles $[52,57]$. For this purpose, the herb was

Table 6. In vivo studies of Dorema spp.

\begin{tabular}{|c|c|c|c|c|c|c|}
\hline Species & Parts used & Type of extraction & Activity & Study design & Result(s) & Ref \\
\hline D. aucheri & Leaves & $\begin{array}{l}\text { Hydroalcoholic } \\
\text { extract }\end{array}$ & Hypolipidemic & $\begin{array}{l}\text { Diabetic rats model; orally; } \\
200 \text { mg/kg for } 4 \text { weeks; } \\
\text { a randomized controlled } \\
\text { clinical trial }\end{array}$ & $\begin{array}{l}\text { Useful in treatment of } \\
\text { diabetes, remarkable } \\
\text { change in serum lipid } \\
\text { profiles }\end{array}$ & [73] \\
\hline D. hyrcanum & Roots & Methanol extract & Antiplasmodial effect & $\begin{array}{l}\text { Mice model; injection ; } 10 \\
\text { mg/mL for } 4 \text { days 4-day } \\
\text { suppressive test against } \\
\text { nicd strain of in mice }\end{array}$ & $\begin{array}{l}\text { Good suppression } \\
\text { plasmodium berghei } \\
\text { infection activity, inhibiting } \\
68.1 \% \text { of the parasite } \\
\text { growth }\end{array}$ & [33] \\
\hline D. aucheri & Leaves & Ethanol95\% & Hepatotoxicity & $\begin{array}{l}\text { Albino mice model; injections; } \\
3.2 \mathrm{~mL} / \mathrm{kg} \text {; three times } \\
\text { every } 48 \text { hours }\end{array}$ & $\begin{array}{l}\text { Inflammation of the liver } \\
\text { tissue, cell proliferation, } \\
\text { cholestasis, and a great } \\
\text { release of liver enzymes }\end{array}$ & [74] \\
\hline D. aucheri & Aerial parts & Essential oil & Anti-diabetic effect & $\begin{array}{l}\text { Patients with type ii diabetes; } \\
\text { randomized clinical trial; } \\
500 \text { mg for } 45 \text { days }\end{array}$ & $\begin{array}{l}\text { Biological effects through } \\
\text { PPAR- } \gamma \text { activation }\end{array}$ & [24] \\
\hline D. urmiana & Aerial parts & $\begin{array}{l}\text { Hydro alcohol } \\
\text { extract }\end{array}$ & Cytotoxicity & $\begin{array}{l}\text { Larvae of artemia urmiana; } \\
24 \text { hours; } 12 \text { mg rutin/g } \\
\text { extract }\end{array}$ & $\begin{array}{l}\text { Ic50 } 76.50 \pm 0.60 \mu \mathrm{g} / \mathrm{mL} \\
\text { potent brine shrimp lethality }\end{array}$ & [64] \\
\hline D. aucheri & Leaves & $\begin{array}{l}\text { Water/ethanol } 95^{\circ} \\
\text { mixture }\end{array}$ & Anti-coccidial & $\begin{array}{l}\text { Chickens model; orally; after } \\
22 \text { day of age; } 30 \mathrm{mg} / \mathrm{kg}\end{array}$ & $\begin{array}{l}\text { Effective in control of } \\
\text { coccidiosis }\end{array}$ & [65] \\
\hline D. ammoniacum & Gum & Water extract & $\begin{array}{l}\text { Anticonvulsant } \\
\text { activity }\end{array}$ & $\begin{array}{l}\text { Male albino mice model; } \\
700 \text { mg/kg; injection }\end{array}$ & $\begin{array}{l}\text { Showed significant } \\
\text { anticonvulsant activity }\end{array}$ & [75] \\
\hline D. aucheri & Root & $\begin{array}{l}\text { Hydroalcoholic } \\
\text { extract }\end{array}$ & $\begin{array}{l}\text { Effects on pituitary } \\
\text { gonad axis } \\
\text { hormones }\end{array}$ & $\begin{array}{l}\text { Adult male rat model; orally; } \\
200 \text { mg/kg for } 28 \text { days }\end{array}$ & Increased Ih concentrations & [76] \\
\hline
\end{tabular}


applied with olive oil on the affected area. Furthermore, many ITM scientists such as Ibn Nafis Qarshi and Jorjani have mentioned the plant as a cure for various types of wounds, ulcers and specifically scars; as Jorjani has written:" Dorema plaster wears away decayed flesh and regenerates new one" $[52,55,57]$.

\section{Joints and muscles}

There are several records on the traditional use of Dorema spp. for joints. For instance, Jorjani has mentioned it for sciatic nerve pain (sciatica). It is also claimed as a cure for arthralgia and stiffness of joints, particularly when prescribed topically with honey $[52,55]$.

\section{PHARMACOLOGICAL ASPECTS}

So far, various pharmacological activities have been reported from Dorema spp., includinganti-microbial, anti-bacterial, antiplasmodial, anti-fungal, cytotoxic, anti-inflammatory, free radical scavenging, hypolipidemic, anticonvulsant and anti-diabetic activities, as well as effects on pituitary gonad axis hormones. These reports have been mentioned in Tables 5 and 6.

\section{CONCLUSION}

Ethnobotanical and traditional medicines are considered as valuable approaches for discovering new medicines because of antiquity medical usage of them over generations. In the current review, the beneficial properties and applications of Dorema spp. Was investigated in ITM books and modern pharmacological studies. The genus Dorema, especially $D$. ammoniacum known as "ushaq" has been used in folklore and Islamic traditional medicine as a treatment for a wide range of disorders, such as gastrointestinal, upper respiratory tract and central nervous systems' problems. Besides, many pharmacological activities including anti-microbial, anti-inflammatory, antioxidant, cytotoxicity, anticonvulsant, anti-diabetic and hypolipidemic activities have been reported in modern medicine. These species contain various constituents such as terpenes, coumarins and phenolic compounds. However, more studies, particularly clinical trials, are necessary to fill existing gaps in our knowledge of various aspects of these species.

\section{ACKNOWLEDGEMENTS}

This work was supported by grants from Research Affairs of Mashhad University of Medical Sciences, Mashhad, Iran.

\section{CONFLICT OF INTEREST}

The authors declare that there are no conflicts od interest.

\section{ORCID}

Elaheh Zibaee, https://orcid.org/0000-0001-9272-7271

Mohammad Sadegh Amiri, https://orcid.org/0000-0003-2892-4523

Zahra Boghrati, https://orcid.org/0000-0002-4771-5690

Faeghe Farhadi, https://orcid.org/0000-0003-1332-3311

Mahin Ramezani, https://orcid.org/0000-0001-5933-6754

Seyed Ahmad Emami, https://orcid.org/0000-0003-4298-3132

Amirhossein Sahebkar, https://orcid.org/0000-0002-8656-1444

\section{REFERENCES}

1. Mozaffarian V. [Flora of Iran]. Tehran: Research Institute of Forests and Rangelands; 2007. Chapter 54, Umbelliferae; p. 368-74. Persian.

2. Rabe SZT, Iranshahi M, Rastin M, Rabe SZT, Mahmoudi M. Anti-inflammatory effect of new kopetdaghins A, C and E from Dorema kopetdaghense. Food Agric Immunol. 2015;26(3):4309.

3. Amin GR. Popular medicinal plants of Iran. 1. Tehran: Iranian Research Institute of Medicinal Plants; 1991. 230 p.

4. Ali GB, Mahdi F. The possibility of crop cultivation and utilization of edible gum from herb (Dorema ammoniacum D. Don) in dryland farming. J Agric Sci. 2015;60(3):369-80.

5. Langenheim JH. Plant resins: chemistry, evolution, ecology and ethnobotany. Portland: Timber Press; 2003. p. 123-9.

6. Amiri MS, Joharchi MR. Ethnobotanical investigation of traditional medicinal plants commercialized in the markets of Mashhad, Iran. Avicenna J Phytomed. 2013;3(3):254-71.

7. Schischkin BK. [Flora SSSR. 17]. Leningrad: Izd-vo Akademii Nauk SSSR; 1951. p. 155-65. Russian.

8. Pimenov MG, Leonov MV, Constance L. The genera of the Umbelliferae: a nomenclator. London: Royal Botanic Gardens; 1993. $156 \mathrm{p}$.

9. Ajani Y, Ajani A, Cordes JM, Watson MF, Downie SR. Phylogenetic analysis of nrDNA ITS sequences reveals relationships within five groups of Iranian Apiaceae subfamily Apioideae. Taxon. 2008;57(2):383-401. 
10. Rechinger KH. Umbelliferae. Graz: Akademische; 1987. p. 37985.

11. Amiri MS, Joharchi MR. Ethnobotanical knowledge of Apiaceae family in Iran: a review. Avicenna J Phytomed. 2016;6(6):621-35.

12. Mosaddegh M, Naghibi F, Moazzeni H, Pirani A, Esmaeili S. Ethnobotanical survey of herbal remedies traditionally used in Kohghiluyeh va Boyer Ahmad province of Iran. J Ethnopharmacol. 2012;141(1):80-95.

13. Memariani F, Akhani H, Joharchi MR. Endemic plants of Khorassan-Kopet Dagh floristic province in Irano-Turanian region: diversity, distribution patterns and conservation status. Phytotaxa. 2016;249(1):31-117.

14. Sadeghei Takallo M, Sajjadifar S, Avval MM. Chemical composition of the essential oils from flowers, stems and roots of Dorema ammoniacum D.Don from Iran. Res J Pharm Biol Chem Sci. 2013;4(4):640-4.

15. Delnavazi MR, Tavakoli S, Rustaie A, Batooli H, Yassa N. Antioxidant and antibacterial activities of the essential oils and extracts of Dorema ammoniacum roots and aerial parts. Res J Pharmacogn. 2014;1(4):11-8.

16. Hosseini SAR, Naseri HR, Azarnivand H, Jafari M, Rowshan V, Panahian AR. Comparing stem and seed essential oil in Dorema ammoniacum D. Don. from Iran. J Essent Oil Bear Plants. 2014; 17(6):1287-92.

17. Zandpour F, Vahabi MR, Allafchian AR, Farhang HR. Phytochemical investigation of the essential oils from the leaf and stem of (Apiaceae) in Central Zagros, Iran. J Herb Drugs. 2016; 7(2):109-16.

18. Masoudi S, Kakavand S. Volatile constituents of the aerial parts of Terataenium lasiopentalum (Boiss.) Manden., stems and leaves of Dorema ammoniacum D. Don. and leaves, fruits and stems of Leutea petiolare (DC.) M. Pimen from Iran. J Chil Chem Soc. 2017;62(1):3311-4.

19. Masoudi S, Esmaeili A, Ali khalilzadeh M, Rustaiyan A, Moazami N, Akhgar MR, et al. Volatile constituents of Dorema aucheri Boiss., Seseli libanotis (L.) W. D. Koch var. armeniacum Bordz. and Conium maculatum L. three Umbelliferae herbs growing wild in Iran. Flavour Fragr J. 2006;21(5):801-4.

20. Akbarian A, Rahimmalek M, Sabzalian MR. Variation in essential oil yield and composition of Dorema aucheri Boiss., an endemic medicinal plant collected from wild populations in natural habitats. Chem Biodivers. 2016;13(12):1756-66.

21. Delnavazi MR, Hadjiakhoondi A, Delazar A, Ajani Y, Tavakoli $S$, Yassa N. Phytochemical and antioxidant investigation of the aerial parts of Dorema glabrum Fisch. \& C.A. Mey. Iran J Pharm Res. 2015;14(3):925-31.

22. Yousefzadi M, Mirjalili HM, Alnajar N, Zeinali A, Parsa M. Composition and in vitro antimicrobial activity of the essential oil of Dorema ammoniacum D. Don. fruit from Iran. J Serbian Chem Soc. 2011;76(6):857-63.

23. Asnaashari S, Dadizadeh E, Talebpour AH, Eskandani M, Nazemiyeh $\mathrm{H}$. Free radical scavenging potential and essential oil composition of the Dorema glabrum Fisch. C.A. Mey roots from Iran. Bioimpacts. 2011;1(4):241-4.

24. Nahvinejad M, Pourrajab F, Hekmatimoghaddam S. Extract of Dorema aucheri induces PPAR- $\gamma$ for activating reactive oxygen species metabolism. J Herb Med. 2016;6(4):171-9.

25. Behpour M, Ghoreishi SM, Khayatkashani M, Soltani N. The effect of two oleo-gum resin exudate from Ferula assa-foetida and Dorema ammoniacum on mild steel corrosion in acidic media. Corros Sci. 2011;53(8):2489-501.

26. Iranshahi M, Shaki F, Mashlab A, Porzel A, Wessjohann LA. Kopetdaghins A-E, sesquiterpene derivatives from the aerial parts and the roots of Dorema kopetdaghense. J Nat Prod. 2007; 70(8):1240-3.

27. Eskandani M, Dadizadeh E, Hamishehkar H, Nazemiyeh H, Barar J. Geno/cytotoxicty and apoptotic properties of phenolic compounds from the seeds of Dorema glabrum fisch. C.A. Bioimpacts. 2014;4(4):191-8.

28. Nurmukhamedova MR, Nikonov GK. Glycosides of Dorema hyrcanum. Chem Nat Compd. 1976;12(1):92-3.

29. Bukreeva TV, Pimenov MG. 2,6-Dihydroxy-4-methoxyacetophenone 2-O- $\beta$-D-gentiobioside from the roots of Dorema aitchisonii. Chem Nat Compd. 1991;27(5):638-9.

30. Delnavazi MR, Hadjiakhoondi A, Delazar A, Ajani Y, Yassa N. Azerosides A and B: two new phloroacetophenone glycosides from the roots of Dorema glabrum Fisch. \& C.A. Mey. Med Chem Res. 2015;24(2):787-96.

31. Nykolov N, Iossifova T, Vassileva E, Kostova I, Stoev G. Reverse-phase high pressure liquid chromatographic analysis of hydroxycoumarins in plant extracts. Quantitative determination of hydroxycoumarins in Fraxinus ornus. Phytochem Anal. 1993;4(2):86-8.

32. Morikawa T, Imura K, Miyake S, Ninomiya K, Matsuda H, Yamashita $\mathrm{C}$, et al. Promoting the effect of chemical constituents from the flowers of Poacynum hendersonii on adipogenesis in 3T3-L1 cells. J Nat Med. 2012;66(1):39-48.

33. Naghibi F, Ghafari S, Esmaeili S, Jenett-Siems K. Naghibione; a novel sesquiterpenoid with antiplasmodial effect from Dorema hyrcanum Koso-Pol. Root, a plant used in traditional medicine. Iran J Pharm Res. 2015;14(3):961-8.

34. Kraus C, Spiteller G. Comparison of phenolic compounds from galls and shoots of Picea glauca. Phytochemistry. 1997;44(1):5967.

35. Lev E, Amar Z. Ethnopharmacological survey of traditional drugs sold in the Kingdom of Jordan. J Ethnopharmacol. 2002; 
82(2-3):131-45.

36. Mohamadi N, Sharififar F, Koohpayeh A, Daneshpajouh M. Traditional and ethnobotanical uses of medicinal plants by ancient populations in Khabr and Rouchon of Iran. J Appl Pharm Sci. 2015;5(11):101-7.

37. Rajaei P, Mohamadi N. Ethnobotanical study of medicinal plants of hezar mountain allocated in South East of Iran. Iran J Pharm Res. 2012;11(4):1153-67.

38. Zarshenas MM, Arabzadeh A, Ajdari Tafti M, Kordafshari G, Zargaran A, Mohagheghzadeh A. Application of herbal exudates in traditional Persian medicine. Galen Med J. 2013;1(2):78-83.

39. Khare CP. Indian medicinal plants: an illustrated dictionary. Berlin: Springer; 2007. 812 p.

40. Chevallier A. The encyclopedia of medicinal plants. London: DK; 1996.336 p.

41. Amini MH, Hamdam SH. Medicinal plants used traditionally in Guldara district of Kabul, Afghanistan. Int J Pharmacogn Chinese Med. 2017;1(3):1-13.

42. Baloch AH, Baloch IA, Haneef-ur-Rehman SRS, Jaffar A. Contribution to the knowledge of ethnobotany of Balochistan, Pakistan. Lasbela Univ J Sci Technol. 2016;1:143-73.

43. Tahvilian R, Shahriari S, Faramarzi A, Komasi A. Ethnopharmaceutical formulations in kurdish ethno-medicine. Iran J Pharm Res. 2014;13(3):1029-39.

44. Mir-Babayev NF, Gasanov GG, Knight DW. Plants of the Republic of Azerbaijan with potential medicinal applications. Int J Pharmacogn. 1993;31(1):47-54.

45. Gintzburger G. Rangelands of the arid and semi-arid zones in Uzbekistan. Montpellier: CIRAD; 2003. p. 91.

46. Emami SA, Nadjafi F, Amine GH, Amiri MS, Khosravi MT, Nasseri M. [Les espèces de plantes médicinales utilisées par les guérisseurs traditionnels dans la province de Khorasan, nord-est de l'Iran]. Ethnopharmacologia. 2012;48:48-59. French.

47. Bibi T, Ahmad M, Ahmadbaloch I, Muhammad S, Manzoor R. Ethnomedicinal uses of plants for child birth and postpartum recovery in District Pishin, Northern Balochistan, Pakistan. Int J Biol Pharm Allied Sci. 2017;6(9):1730-60.

48. Koohpayeh A, Ghasemi Pirbalouti A, Yazdanpanah Ravari MM, Pourmohseni Nasab E, Arjomand D. Study the ethno-veterinary of medicinal plants in Kerman province, Iran. J Herb Drugs. 2011;2(3):211-6.

49. Sadeghi Z, Mahmood A. Ethno-gynecological knowledge of medicinal plants used by Baluch tribes, southeast of Baluchistan, Iran. Rev Bras Farmacogn. 2014;24(6):706-15.

50. Ibn Sina H. [Al-Qanun fi'l-Tibb (Canon of medicine)]. New Delhi: Jamia Hamdard; 1998. p. 30. Arabic.

51. Ibn al-Baytar AA. [Al-Jamee le-Mofradaat al-Adwiah wa alAghziyah (Book in simple drugs and foods)]. Beirut: Dar al-
Kotob al-Ilamiyah; 1992. p. 47-48. Arabic.

52. Husseini Tonekaboni MM. [Tohfah al-Momenin (Rarity of the faithful)]. Tehran: Shahr Publishers; 2008. p. 47. Persian.

53. Ghasani AM. [Hadiqat al-Azhar fi Mahiyyat al-ushb wa aluqqar]. Beirut: Dar al-Gharb al-Islami; 1990. p. 38. Arabic.

54. Aqili Khorasani MH. [Makhzan al-Adwiah (Drug treasure)]. Tehran: Sabz Arang Publisher; 2014. p. 170-1. Persian.

55. Ibn Nafis Qarshi AD. [Al-Mujaz fi'l-Tibb (A Commentary on Ibn Sina’s Canon)]. Cairo: Ihyaa al-Torath al-Islami; 2001. p. 83. Arabic.

56. Jorjani SEI. [Al-Aghraz al-Tibbia val Mabahess al-Alaiia (Medical goals and Allaii's discussions)]. Tehran: University of Tehran Press; 2006. p. 284. Persian.

57. Antaki D. [Tazkere oulol-albab (Memorandum book)]. Beirut: Dar-al-Kotob al-ilmiyah; 2000. p. 51. Arabic.

58. Jorjani SE. [Zakhire Kharazmshahi (Treasure of Kharazmshah), photo print of the manuscript dated 1206]. Tehran: AD Sirjani; 1976. p. 191. Persian.

59. Rajani M, Saxena, N, Ravishankara MN, Desai N, Padh H. Evaluation of the antimicrobial activity of ammoniacum gum from Dorema ammoniacum. Pharm Biol. 2002;40(7):534-41.

60. Kumar VP, Chauhan NS, Padh H, Rajani M. Search for antibacterial and antifungal agents from selected Indian medicinal plants. J Ethnopharmacol. 2006;107(2):182-8.

61. Abedini A, Roumy V, Mahieux S, Gohari A, Farimani MM, Rivière $\mathrm{C}$, et al. Antimicrobial activity of selected Iranian medicinal plants against a broad spectrum of pathogenic and drug multiresistant micro-organisms. Lett Appl Microbiol. 2014; 59(4):412-21.

62. Mianabadi M, Hoshani M, Salmanian S. Antimicrobial and antioxidative effects of methanolic extract of Dorema aucheri Boiss. J Agric Sci Technol. 2015;17(3):623-34.

63. Yazdi FT, Behbahani BA, Vasiee A, Mortazavi SA, Yazdi FT. An investigation on the effect of alcoholic and aqueous extracts of Dorema aucheri (Bilhar) on some pathogenic bacteria in vitro. J Paramed Sci. 2015;6(1)58-64.

64. Mirzaei A, Mirzaei N, Ghavamizadeh M. Antioxidant activity and cytotoxicity of Dorema aucheri by Artemia urmiana: a brine shrimp lethality test. Life Sci J. 2013;10:8-12.

65. Habibi H, Firouzi S, Nili H, Razavi M, Asadi SL, Daneshi S. Anticoccidial effects of herbal extracts on Eimeria tenella infection in broiler chickens: in vitro and in vivo study. J Parasit Dis. 2016;40(2):401-7.

66. Khan A, Farooq U, Ullah F, Iqbal J, Khan AF, Zaib S, et al. Determination of biological activities and total phenolic contents of flowers of Jasminum humile and roots of Dorema aucheri. J Chem Soc Pak. 2014;36(2):291-5.

67. Etebari M, Sajjadi SE, Jafarian-Dehkordi A, Nazmakanipour 
S. Genotoxicity evaluation of hydroalcoholic and aqueous extracts of Dorema aucheri by the comet assay. Adv Biomed Res. 2016;5:199.

68. Jafari N, Zargar SJ, Yassa N, Delnavazi MR. Induction of apoptosis and cell cycle arrest by Dorema glabrum root extracts in a gastric adenocarcinoma (AGS) cell line. Asian Pac J Cancer Prev. 2016;17(12):5189-93.

69. Bannazadeh Amirkhiz M, Rashtchizadeh N, Nazemiyeh H, Abdolalizadeh J, Mohammadnejad L, Baradaran B. Investigating apoptotic effects of methanolic extract of Dorema glabrum seed on WEHI-164 cells. ISRN Pharmacol. 2013;2013:949871.

70. Shahidi GH, Moein MR, Foroumadi AR, Rokhbakhsh ZF. Cytotoxic activity of medicinal plants used in Iranian traditional medicine on two strains of Saccharomyces cerevisiae. Daru J Pharm Sci. 2002;10(4):162-4.

71. Mosaddegh M, Esmaeili S, Naghibi F, Moghadam MH, Haeri A, Pirani A, et al. Ethnomedical survey and cytotoxic activity of medicinal plant extracts used in Kohgiluyeh and Boyerahmad province in Iran. J Herbs Spices Med Plants. 2012;18(3):211-21.

72. Bannazadeh Amirkhiz M, Rashtchizadeh N, Nazemieh H, Ab- dolalizadeh J, Mohammadnejad L, Baradaran B. Cytotoxic effects of alcoholic extract of Dorema glabrum seed on cancerous cells viability. Adv Pharm Bull. 2013;3(2):403-8.

73. Ahangarpour A, Zamaneh HT, Jabari A, Nia HM, Heidari H. Antidiabetic and hypolipidemic effects of Dorema aucheri hydroalcoholic leave extract in streptozotocin-nicotinamide induced type 2 diabetes in male rats. Iran J Basic Med Sci. 2014; 17(10):808-14

74. Mostafavi SH, Fazilati M, Mostafavi SA, Vahhabi MR, Mostafavi F, Omidvarinia S, et al. Hepatotoxicity of Dorema aucheri (Bilhar) in albino mice. Arch Iran Med. 2013;16(9):530-2.

75. Motevalian M, Mehrzadi S, Ahadi S, Shojaii A. Anticonvulsant activity of Dorema ammoniacum gum: evidence for the involvement of benzodiazepines and opioid receptors. Res Pharm Sci. 2017;12(1):53-9.

76. Khatamsaz S, Azarnioshan F, Sadeghi H. Effects of hydroalcoholic extract of Dorema aucheri on pituitary-gonad axis hormones in adult male rats. Nat Environ Pollut Technol. 2010;9(3): 507-11. 